Proceedings of the Prehistoric Society 63, 1997, pp. 55-86

\title{
Radiocarbon Dating and the Prehistory of the Balearic Islands
}

\author{
By Pedro V. Castro Martínez, Sylvia Gili Suriñach, Paloma González Marcén, \\ Vicente lull, Rafael Micó Pérez and Cristina Rihuete Herrada ${ }^{1}$
}

The aim of this paper is to establish an absolute chronology for the prehistoric entities and sites of the Balearic islands. We begin with the buman settlement of each island and continue with the temporalities of the most important entities and materials of the Pretalayotic period: the Beaker phenomenon, megalithic tombs, artificial burial caves, naviforms, and navetas. Then we define the chronological limits of the Talayotic period, giving special attention to its internal sequence and to the chronology of its distinctive monuments - the talayots, sanctuaries, and taulas. Finally we suggest the chronological limits of the material and sites ascribed to the Post-talayotic period. The approach adopted bere is based on a detailed analysis of the radiocarbon dates corresponding to the main archaeological periods mentioned above. The information potential of each date has been evaluated critically in terms of the archaeological contexts from which samples were obtained.

\section{THE ARCHAEOLOGY OF THE BALEARIC ISLANDS: CURRENT STATE OF AFFAIRS}

Research into Balearic prehistory, which started at the beginning of the century, has tended to centre on four major periods. The first one corresponds broadly to what Waldren (1982) has termed the 'First settlement period'. The second, labelled 'Pretalayotic', is associated with the earliest contexts to contain pottery and combines a whole series of archaeological phenomena, as we shall see. The third brings together, under the name of 'Talayotic', all the material expressions which tend to accompany a type of construction known as a talaiot (dry stone towers built with large stones and usually conical or quadrangular in outline). Finally, the last period is identified by the presence of iron objects coinciding precisely with the moment when the talaiot fell into disuse. According to some authors, this period is seen as a Late Talayotic, while others have defined it as a separate and independent entity, the 'Post-talayotic'. However, issues of actual terminology apart, these periods are based on the idea that the presence or

\footnotetext{
${ }^{1}$ Departament d'Antropologia Social i de Prehistoria, Universitat Autonoma de Barcelona, Edifici B, 08193 Bellaterra, Barcelona, Spain

Received August 1996. Accepted April 1997
}

absence of the talaiots constitutes a key discriminating factor in establishing a cultural sequence for the islands.

It is important to point out, however, that research which has generated this cultural sequence has centred on the two largest islands of the archipelago (Mallorca and Menorca), with the emphasis upon Mallorca. The archaeology of the Pitiussae (Ibiza and Formentera) has focused on the role of the Punic-Phoenician colonisation of the island of Eivissa (Ibiza) and only recently have there been more systematic studies on the early settlement which will allow us to articulate the dynamics of the prehistoric socio-economy of Eivissa and Formentera with those of Mallorca and Menorca.

At the same time, the investigation into the prehistoric sequence of the Balearic islands must contend with another series of problems which concern, above all, the attempt to produce a sequence which makes archaeological and chronological sense. One of the principal factors which has led to this state of affairs is the scarcity of systematic excavations; fieldwork tends to be sporadic and not very standardised. The study of finds shows similar deficiencies, which poses an added problem when it comes to carrying out syntheses of the historical dynamics of the communities of the archipelago. At first 
glance, the prospects for the chronology should be more favourable, taking into account the extensive radiocarbon series associated with the archaeological sites of the islands. However, these dated sites are by no means evenly distributed throughout the archaeological landscape, as there is a greater concentration in Mallorca and, more precisely, in a few sites situated in the Tramontana mountain range in the north of the island. It is also important to bear in mind that the majority of dates are insufficiently contextualised, and so their utility is considerably diminished. In spite of these difficulties, the information relating to the radiocarbon dates can be combined with the available archaeological data in an attempt to place the archaeological entities of the islands in chronological order.

\section{STRUCTURING THE PREHISTORIC SEQUENCE OF THE BALEARICS: PERIODS AND 'CULTURES'}

The archaeology of the Balearic islands is no exception to the common practice of establishing tripartite divisions (Waldren 1982). The three main phases mentioned earlier, Pretalayotic, Talayotic, and Post-talayotic, are preceded by a still uncertain interval related to the initial human settlement on the islands. However, in contrast to the classical European periodisations, the Balearic periods do not fit with the traditional metal 'Ages': the Pretalayotic extends further in time beyond the conventionally accepted duration of the Copper Age, the Talayotic behaves equally with the Bronze Age, and the Post-talayotic starts after the accepted beginning for the Iron Age.

Within this framework, the Talayotic becomes the central focus around which everything earlier and later takes on meaning. The splendour of its architectural constructions (talaiots) and the considerable homogeneity of the artefactual assemblage have contributed to making it the only entity which can be termed an 'archaeological culture' which, at the same time, has its very own subdivision into phases (Rosselló-Bordoy 1973; Fernández-Miranda 1978a). On the other hand, the Pretalayotic period is defined as one which includes very heterogeneous expressions (domestic activity occurring both in caves and openair settlements, megalithic tombs, Beaker wares, copper technology) in a variety of combinations, preceded by a 'prologue' based somewhat tenuously upon evidence regarding the initial stages of human settlement. As for the Post-talayotic, its reliance upon the Talayotic period is clearly seen, in that for some authors it does not represent an autonomous entity but rather the final stages of the latter (RossellóBordoy 1973; Fernández-Miranda 1978a).

In view of the current situation regarding research, is it possible to maintain the traditional chronology, redefining it in terms of recurrent cultural assemblages? In other words, is it possible to ask whether the traditional entities can conform to archaeological groups as such (González Marcén et al. 1992)? At first glance, only the Talayotic period seems to comply with this, due to the lack of analytical studies regarding the other cultural expressions. Given this situation, could the temporal dimension, expressed in radiocarbon dating, contribute at least to the definition of each one of them?

The exercise of organising time in relation to the concentrations of the values obtained through calibrated radiocarbon dates can be interpreted in terms of rupture or continuity in population, so that we may infer changes in historical dynamics. In this sense it would be important to consider the temporal intervals with enormous concentrations of radiocarbon dates as moments in time when an intensive exploitation of the natural resources for social gain took place (felling trees, slaughtering vertebrates). In this way we would define key moments in the exploitation of natural resources which would affect the islands and that, by way of an hypothesis, we could compare to episodes of rupture or change in social dynamics. However, we would still lack a code which would enable us to give them social meaning. Social significance can only be attributed by archaeologists through objects and these can only be understood in the context of material assemblages, rarely defined in Balearic archaeology. Dates place objects in time, but they do not offer meaning; they merely provide a 'precondition' so that the latter can be attributed. In this paper, we will be content if we can complete the first stage, knowing that many years of research are required for the second to be achieved.

\section{THE RADIOCARBON SEQUENCE OF THE BALEARIC ISLANDS}

At this moment in time we have 191 dates $^{1}$ associated with sites found in the Balearic islands and related to archaeological contexts linked with human occupation (Appendix). In comparison with the list of radiocarbon dates for the Iberian peninsula, the 


\section{P.V. Castro Martínez et al. RADIOCARBON DATING AND BALEARIC PREHISTORY}

Balearic islands are second (after Andaluciá and Portugal) in terms of the number of radiocarbon dates associated with the autonomous communities, comprising just over $10 \%$ of the total (Castro, Lull \& Micó 1996). It is worth noting that the Balearics occupy second position, after Euzkadi, with regard to the density of dated sites per square $\mathrm{km}$ and that the most complete radiocarbon sequence of sites is concentrated in one of its islands (Mallorca). The privileged position of Mallorca is due to the efforts of William Waldren and his research centre in Deià, where for more than 30 years the need to obtain a wide range of absolute dates has been recognised. Two of the sites excavated by this scholar, Son Matge and Son Ferrandell-Oleza, offer the most complete series of the Iberian peninsula, with about 50 dates for each (op. cit.)

The advantages derived from a large regional series such as that of the Balearic islands are countered by two serious problems. In the first place, $75.6 \%$ of the dates are derived from just five sites (Son FerrandellOleza, Son Matge, Son Mas, Son Fornés, and Torralba d'en Salord) and these five represent only $17.8 \%$ of all the sites with available dates. In other words, the remaining 23 sites present an unrepresentative series which fluctuate between one and four dates. Secondly, the quantity of dates for each one of the islands is very uneven. In fact, the Balearic series is really synonymous with the Mallorcan series, in that about $86 \%$ of the total number of dates come from this island, leaving Menorca behind with $12.4 \%$, Eivissa with $1.03 \%$, and Formentera $0.5 \%$. If we add to this the fact that more than half the dates for Menorca come from one site alone (Torralba d'en Salord), it seems fairly obvious that the Balearic series depends fundamentally on the absolute sequence of Mallorca.

The considerable differences, both in quantity and quality, between the site series and the scarcity of dates for the smaller islands, make it impossible to attempt a comparative study of each of the archaeological groups, site types, and materials between the islands. Nevertheless, we will try to review the sequence for the Balearic islands and suggest a chronology which is more in line with the radiocarbon dates of the various archaeological groups. As far as possible, we will also attempt to outline the different archaeological expressions which characterise such a chronology. In text and illustrations all date ranges quoted are based on the 1 sigma standard deviations for calibrated dates.
Of the Balearic series we have mentioned so far, we will dispense with dates of the last 2000 years, which are not relevant to the purposes of this study, and also with dates which have been affected by various problems relating to their recovery (for details, see Appendix). Of the 29 dates belonging to this group, 18 come from Son Matge (QL-23, QL-9 QL-5b, QL11, QL-22, QL-1a, QL-24, QL-7, QL-5, QL-7a, QL5a), 2 from Torralba d'en Salord (BM-1697, CSIC142) and Son Ferrandell-Oleza (BM-1988R, BM1842R), and 1 from Sa Regina dels Cans (QL-146), $\mathrm{Ca} \mathrm{Na}$ Costa (BM-1677), Cova dels Morts-Son Gallard (Y-2672), Son Fornés (UGRA-121), Son Mas (IRPA-1066), Son Oms (BM-1692), and S'Illot des Porros (Y-4584).

\section{THE ORIGINS OF THE FIRST SETTLERS OF THE ISLANDS}

The most consistent archaeological evidence in relation to the first human presence in the Balearic islands comes from two sites on the island of Mallorca: Son Matge in Valldemossa and Son Muleta in Sóller. In the Son Matge rock shelter, hearths were discovered associated with the remains of a now extinct, endemic species Myotragus Balearicus. Some bones of this animal appear to have shown characteristic signs of butchering. It has also been suggested that some horns had been 'trimmed' by human beings to avoid the injuries they could inflict upon themselves in the rock shelter, which possibly acted as a stable (Waldren 1982). The dates for this occupation cover a time frame which includes the 6th-5th millennia BC. In Son Muleta, human remains belonging to four or five individuals and bone and flint implements were found in association with Myotragus Balearicus. The dates available for this site suggest that this archaeological association was taking place towards the beginning of the 5 th millennium $\mathrm{BC}$.

This evidence demonstrates the existence of these first communities between the 6th-4th millennia $\mathrm{BC}$ (Appendix). The data originates principally from the area of the Tramontana mountain range, where the vegetation consisted mostly of pine and brushwood and whose natural caves were used for shelter or domestic purposes, in the context of subsistence practices based on hunting and gathering and the systematic exploitation of Myotragus. However, some open air flint workshops recorded at several sites in the municipality of Santanyí (Carbonell et al. 1981; Pons-Moyà \& Coll 1984) could alter the view we 
have outlined and even suggest the existence of a hitherto unsuspected epi-mesolithic context. Unfortunately, these studies are in their initial stages and are based upon typological analysis of stone industries.

On the other hand, in Mallorca, the earliest dates associated with simple, undecorated pottery come from Son Matge and Cova dels Morts-Son Gallard (Deià) and are dated to the beginning of the 4th millennium cal. BC. On Menorca, the appearance of the remains of Myotragus with evidence of human intervention is associated with pottery. This fact seems to suggest that human settlement on Menorca was later than on Mallorca and could have occurred between the first half of the 4th and mid 3rd millennia cal. BC, coinciding with the radiocarbon dates associated with the last Myotragus of Mallorca.

Ibiza and Formentera are, for the moment, lacking in evidence which would make their earliest occupation synchronous with that of Mallorca and Menorca. Without any other source of evidence showing the early presence of human beings in the Pitiussae, the chronology of the first human settlement has to be inferred from the earliest known archaeological remains which do not seem to occur before the 3rd millennium $\mathrm{BC}$.

The origin of the first settlers remains a mystery. The theories proposed are centred upon the pottery types recorded on Mallorca, which are dated two millennia later. The simple techniques employed in their manufacture and the scarcity of these items makes the reliability of this evidence questionable when it comes to formulating hypotheses of their origin. In spite of this, Waldren (1982) has suggested that the pottery shares similarities with continental Neolithic types, highlighting in particular those which are associated with the Neolithic Catalan fosa graves. In his opinion, the origin of the first groups of people who settled on the islands would have to have been in the north-east of the Iberian peninsula (Gili Suriñach et al. 1996).

\section{THE PRETALAYOTIC GROUPS}

The available Pretalayotic record is full of gaps, due to the fact that it has been compiled from excavations which have been neither standardised nor systematic. The record comprises an extensive array of architectural forms which, in the case of domestic structures, varies from natural caves to open air settlements built in stone. In the funerary sphere we find natural caves, rock-cut tombs, megalithic tombs, and navetas. Several artefactual assemblages appear in this range of structural contexts.

\section{The Beaker ware question}

The radiocarbon dates associated with the stratigraphic contexts of Son Ferrandell-Oleza (Waldren 1982; 1984; 1986; 1990; 1992; Waldren et al. 1990) and Son Matge (Rosselló-Bordoy \& Waldren 1973; Fernández-Miranda \& Waldren 1974; Waldren \& Plantalamor 1975; Waldren 1982; 1986; 1992) seem to indicate that we should place the first Beaker ware finds on the island of Mallorca parallel to the beginnings of extensive and organised settlement on the islands $c .2500-2450$ cal. BC. The most important settlement, Son Ferrandell-Oleza, constitutes an open air settlement of about $3600 \mathrm{~m}^{2}$ surrounded by a rectangular wall with reinforcements in two of its corners and a small guardpost in one of the entrances to the site. Two stone pseudo-naviform structures were excavated, together with a water channel which ran from a water cistern immediately outside of the wall. Nothing resembling this complex has ever been recorded in any other location on the islands, unless one includes the walled structures of Can Sargent II in Eivissa, and Sa Cala in Formentera (Fernández Gómez 1977; Gómez et al. 1989; Costa \& Fernández Gómez 1992).

Beaker ware is recorded at Son Ferrandell-Oleza practically throughout its whole occupation (c.2500-1300 cal. BC) and can be divided into two types, both with incised decoration. The first appears predominantly on bowls and is similar to the Catalan Salamó style, although some fragments are more in line with the Bois Sacré style from southern France. Either way, they both usually have dates prior to the beginning of the 2nd millennium cal. $\mathrm{BC}$, but not much earlier. The second Beaker ware decoration type is related to the Arboli pottery style which originates from the north-east of the Iberian peninsula and is later in date (c. 2250-1800 cal. BC).

In the Son Ferrandell-Oleza excavations, crucibles and copper ingots have also been recorded. This evidence of metal technology is comparable with that recorded at Son Matge, where not only did the same kind of utensils appear in association with Beaker ware, but there were also two decorated fragments which still preserved traces of copper oxide in their interiors, It is, of course, important to bear in mind 


\section{P.V. Castro Martínez et al. RADIOCARBON DATING AND BALEARIC PREHISTORY}

that both sites are located in the Tramontana mountain range, one of the few places in the Balearics, including a few sites on Menorca, with evidence of copper veins.

On the mainland, Beaker ware is usually associated with projectile points of the Palmela type, small triangular or tanged daggers, archers' wristguards and bone buttons. Burials closely linked to the Beaker ware sphere tend to be found in cists, shafts, or megalithic tombs. Among the evidence of insular distribution of this assemblage we find tanged daggers, like that in the museum of Eivissa (Costa $\&$ Fernández Gómez 1992, 298) or one found in the natural cave of Son Primer 24, Mallorca (Veny 1968), and the leaf-shaped arrowheads from Es Rafal D'es Toro and Ses Roques Llises, Menorca (RossellóBordoy et al. 1980). Beaker ware has also been documented in natural habitation caves, such as at Cova dels Bous and Son Torrella (Veny 1968), though in disturbed archaeological contexts. A more interesting case is the probable deposition of Beakers as grave-goods in a possible burial cist excavated at Cova dels Morts-Son Gallard, Mallorca (Waldren 1982), although the publication of this site does not provide a sufficiently detailed record.

The only archaeological context comparable to Son Ferrandell-Oleza and Son Matge is that of level $\mathrm{C}$ at $\mathrm{Ca} \mathrm{Na}$ Cotxera (Cantarellas 1972a, 49-63; 1972b), also in Mallorca. It comprises a subrectangular construction containing a large number of Beaker ware fragments and has a date centred on c. $2200 \mathrm{cal}$. BC. Lastly, we must also mention the impressive collection of Beaker wares discovered under the main structure of the Son Mas sanctuary, Mallorca (Waldren et al. 1988; 1989; Waldren \& van Strydonck 1992), although we will have to wait for a more complete publication before we can assess its value.

The majority of the pottery found at Son Ferrandell-Oleza, Son Matge, and Ca Na Cotxera is composed of undecorated types usually accepted as Pretalayotic, which have also been recorded on Menorca, although not in association with Beaker wares. This situation poses a big problem: when and from where did the colonisation of the lowlands of Mallorca and the rest of the islands take place?

It seems feasible to propose the existence of a local, underlying population identified through the presence of simple, plain pots, usually globular, spherical, conical, or biconical in shape and recorded at natural caves or rock-shelters (Late Neolithic of Son Matge), to which continental Beaker ware influences were added. These provided the technology necessary in the manufacture of copper objects and probably subsistence strategies based on cultivation and animal husbandry which demanded the colonisation of the lowlands due to the proximity of potentially arable land. One alternative theory could also suggest that the colonisation of these lands was carried out by the local communities prior to the arrival of the Beaker ware influence. However, this idea is hindered by the lack of evidence relating to the usage of the naviform structures prior to the arrival of the Beaker ware traditions in the lowlands.

All in all, neither of the two theories clarifies the chronological dilemma of the megalithic tombs which, on the mainland, occur earlier than - or at least contemporary with - Beaker ware traditions.

\section{Balearic megalithic tombs}

Megalithic structures in the islands are rare. Until recently, only four examples from south-east Menorca were known (Alcaidus: Plantalamor 1976/7; Ses Roques Llises: Rosselló-Bordoy et al. 1980; Montplé: Plantalamor 1976/7; Binidalinet: Plantalamor 1977), one in Mallorca (Son Bauló de Dalt: Rosselló-Bordoy 1965) and another in Formentera (Ca Na Costa: Fernández Gómez et al. 1976). However, surveys on the island of Menorca have identified the existence of new monuments in the northern and north-western sectors of the island (Górnes et al. 1992). In Ciutadella, four have been recorded (two in Son Escudero, one in Son Salomó and another in Rafal d'es Capità), one in Ferreries (Son Ermità) and another in Mercadal (Ferragut Nou). Of all the above-mentioned, it is important to note that the last two structures are more in line with the traditional megalithic expressions, both artefactually and formally. Lastly, we must mention that a possible tomb has also been recorded on the island of Eivissa (Can Sargent I) and consists of a $2 \mathrm{~m}$ passage and the possible remains of a circular chamber. Nevertheless, it seems somewhat premature to ascribe to it a funerary function, as the supposed associated cultural assemblage is chronologically inconclusive and the dates for the human bone are completely anachronistic. The cited dates (BM-1510, BM-1511; (Fernández Gómez \& Topp 1984, 767; Gómez Bellard \& San Nicolás Pedraz 1988, 211) are outside the chronometric range established for megalithic finds in the Iberian peninsula (Castro, Lull \& Micó 1996). 
All the Menorcan megalithic constructions seem to correspond to a small type of tomb with a passage and a square or oval chamber accessible through a perforated stone slab, which acts as a portal. On some occasions, supporting walls or external reinforcements encircling the chamber and passage are preserved. Among the small amount of finds which make up the grave-goods, there are conical shaped vessels with incised cordons below the rim, bowls, and pseudo-cylindrical and carinated vessels. At Ses Roques Llises were found a pyramidal V-perforated bone button, a leaf-shaped arrowhead which has echoes of the Palmela type, and a copper/bronze point with a square cross-section that could be its stem. Among the recently discovered northern sites, similar finds have been recorded at Son Ermitá.

In view of the fact that, for some researchers (Plantalamor 1992), these tombs with passages are associated with the first stages of the Menorcan Pretalayotic period, outside influences have had to be traced in order to explain the initial settlement of the island. Some inconclusive similarities have been drawn with places like Corsica, Sardinia, southern France, Languedoc, Catalonia, and also south-eastern Spain.

Son Bauló de Dalt, the only Mallorcan tomb known to date, is similar in its proportions to the Menorcan type but not architecturally, nor in terms of the grave-goods. Regarding the finds, it is important to point out the absence of the conical shaped vessel with incised cordon below the rim and the presence of various flat bases and over half a dozen flint flakes.

Summing up, the archaeological materials recorded in the megalithic tombs coincide with the cultural assemblages associated with the Beaker ware traditions, although there is a clear difference in the context of their appearance on the main islands: on Mallorca they tend to appear in domestic situations, whereas on Menorca the majority are associated with tombs. The materials which accompany both entities, megalithic and Beaker ware traditions, fall into two categories: on the one hand, locally produced undecorated pottery, and on the other, non-ceramic artefacts of continental type found in megalithic contexts reutilised by communities equipped with Beaker ware assemblages, after their construction.

\section{Rock-cut tombs or artificial burial caves}

On the Spanish mainland, artificial burial caves constitute a type of archaeological expression tradi- tionally associated with megalithism. The ones we are concerned with here have only been detected on Mallorca and Menorca (Veny 1968; 1970; 1976a; Plantalamor \& Rita 1982) and they are structurally similar in that they all possess an apsidal or elongated chamber. These rock-cut tombs are locations where multiple inhumations took place, either in single units, or in groups of five (Cala Sant Vicent), six (Son Toni Amer), and even eight, caves (Son Sunyer) (Mallorca).

Apart from the above-mentioned, structural, common factor, the rock-cut tombs differ in other aspects. Examples have been recorded with access passages (Es Cabás), internal long benches ( $\mathrm{Na}$ Fonda, Son Amer), side chambers, or even niches (d'en Bordoy, Colònia de Sant Pere). Access to the main chamber takes various forms ranging from a simple opening communicating with a small passage to structures made of large slabs enclosing a ramp, steps, or a well (Son Jaumell, Son Toni Amer).

On Mallorca, rock-cut tombs are evenly dispersed throughout the island from the eastern mountains surrounding the Massis d'Artá, to the mountainous north. They have also been recorded in the Es Pla (the lowlands) and are quite numerous in the southern regions of the island. Among the archaeological finds, undecorated wares are common, and are predominantly spherical vessels with open mouths and small perforated handles attached to the top half of the pot, although spherical bowls and conical shaped and pseudo-cylindrical vessels have been recorded. The rest of the funerary finds comprise copper riveted daggers, arrowheads and points, discoidal bone beads, perforated bone buttons and flint flakes, sharpeners, arrowheads, and archer's wristguards.

\section{Naviform structures and the Navetas}

The term 'naviform' refers to structures composed of two almost parallel double faced walls joined together at one end with an apsidal or horseshoe shaped construction (Els Closos de Can Gaià: RossellóBordoy \& Frey 1967; Es Figueral de Son Real: Rosselló-Bordoy \& Camps 1972; Alemany: Enseñat Enseñat 1981). In some instances they have a central hearth, usually sub-rectangular, which may also have a ledge (Son Oms: Rosselló-Bordoy 1979, 102-6; Canyamel: Rosselló-Bordoy \& Camps 1976). The roofing, which would have comprised a timber framework covered with branches, rested on wooden posts placed along the central axis of the structure. 


\section{P.V. Castro Martinez et al. RADIOCARBON DATING AND BALEARIC PREHISTORY}

Only in one case (Cova d'es Moro de Son Mercer de Baix) has a stone roofing structure made up of stone slabs resting on Mediterranean type columns been recorded (tapering at the base). Isolated naviforms are common, although they can also appear adjacent to others such as at Can Roig Nou (Rosselló-Bordoy 1966). The aggregation of constructions, either in pairs, in threes, or in close proximity, has been interpreted as evidence for the existence of groups of extended families.

The distribution of the nearly 70 naviforms in Mallorca tends to be concentrated in the coastal lowlands. The areas with a greater frequency of structures lie to the east and south of the Levant mountain range, in the southern foothills of the Tramontana mountains and, in smaller numbers, on the plains and around the bay of Alcudia. On Menorca, the number of structures comprises less than one-tenth the number of recorded Mallorcan sites and the majority are exclusively concentrated in the southern half of the island. The artefactual repertoire recovered from the interior of this type of construction is made up of globular, biconical and conical shaped and hemispherical vessels. The high frequency of fragmentation of these vessels makes it somewhat difficult to carry out typological studies, the only possibility being the confirmation of the absence of conically shaped profiles with incised rims (characteristic of caves and, above all, of the megalithic tombs) and the relative frequency of flat bases, a feature that is not common until the peak of the Talayotic era. Both aspects, together with the relative frequency of typical Talayotic pottery in Mallorcan naviforms (Can Roig Nou, Es Figueral de Son Real) and Menorcan ones (Son Mercer de Baix: Anglada 1976; Plantalamor \& Rita 1984; Rita 1988; Sa Torreta, Clariana: Plantalamor 1976; Plantalamor et al. 1977; Plantalamor \& Anglada 1981), suggest that some of them, especially those which are grouped together, correspond with a phase of transition into the Talayotic period. The typically early Talayotic metal objects recovered from the naviforms of Can Roig Nou and Son Mercer de Baix are equally transitional.

Although it is not possible to confirm the existence of naviforms in the Pitiussae, structures such as those at Cap de Berberia II, Formentera (Gómez Bellard \& San Nicolás Pedraz 1988; Costa \& Fernández Gómez 1992) are reminiscent of this kind of construction.

True navetas are recorded only on Menorca, where they are distributed throughout most of the island (Es
Tudons: Florit 1966; Serra et al. 1977; La Cova: Veny 1982; Son Morell: Veny 1974; 1976b; Binipati Nou: Plantalamor \& Sastre 1991; Rafal Rubí: Serra \& Rosselló-Bordoy 1971; Biniac-L'Argentina: Serra 1965; Plantalamor \& López Pons 1983; Cotaina and Sa Torreta: Murray 1934). Their external appearance is almost identical to that of the naviforms, although they do not occur in groups but in isolation and are exclusively designed as places of collective burial. They consist of a very small entrance, sometimes a perforated stone slab, giving way to a narrow passageway or a small rectangular or trapezoidal antechamber through which access is gained to an elliptical or elongated chamber. The roofing is of tightly fitting dry-stone construction.

The repertoire of recovered objects is confined to conical and hemispherical vessels, bone buttons, bone pendants and beads, and a few copper and bronze artefacts, predominantly arrowheads, points, bracelets, razors, and tubular rods with biconical ends sometimes known as 'bridles' (Delibes \& FernándezMiranda 1988).

The absence of triangular daggers and globular pottery, typically associated with both Mallorcan and Menorcan burial rock-cut tombs, and the continuity of some of their materials in Talayotic contexts (such as the V-perforated bone buttons, bronze bracelets, and the conical vessels with flat bases), place the navetas in a transitional phase between the Pretalayotic and the Talayotic periods. We consider the traditional viewpoints of, say, Pericot (1975) (who placed the burial navetas in the Early Talayotic period and associated their appearance with a typological evolution of the collective inhumation practised in the rock-cut tombs), more empirically acceptable than recently proposed theories (Plantalamor 1991; 1992), according to which the navetas with circular or oval shaped plan, known as 'Intermediate type' (BiniacArgentina) are proposed as models derived from the megalithic tombs using cyclopean building techniques, and would thus constitute an immediate antecedent of the Menorcan burial navetas.

This transitional phase, which took place in the Mallorcan and Menorcan naviforms and the Menorcan burial navetas, brings together two distinct dynamics. The first, and chronologically earlier, is characterised by horizontally dispersed settlements occupying intramontane valleys and natural caves, with burial practices initially taking place in dolmens and later in rock-cut tombs. The second, known as the 
Talayotic period, possesses a radically different archaeological manifestation which is discussed below.

\section{The relative chronology of the Pretalayotic}

The Pretalayotic sites and finds appear as heterogeneous combinations which pose considerable problems when it comes to proposing a relative chronology. Pottery with Beaker ware designs has not been found in either navetas or rock-cut tombs, and only marginally in megalithic tombs (one fragment in $\mathrm{Ca} \mathrm{Na}$ Costa, Formentera). Its presence is also concentrated mainly in the northern sector of the island of Mallorca (Cantarellas 1972a). Beaker ware is frequent in funerary contexts on the mainland, but not so in the Balearic islands where the Beaker ware assemblage also offers a very wide chronological span, as can be seen in the series provided from the settlement of Son Ferrandell-Oleza (Appendix). In view of the absence of Beaker wares in certain burial structures such as navetas and rock-cut tombs, it is considered that the human groups utilising them were different from those who possessed Beaker ware in their artefactual assemblages, although the dilemma lies in establishing whether or not both groups were synchronous. If we opt for this last possibility, then maybe the megalithic tombs were earlier or, at least, slightly synchronous with the Beaker ware traditions and the navetas were later. In order to resolve this dilemma, radiocarbon dating is clearly required.

Artefacts traditionally associated with the Beaker ware tradition (undecorated pottery, tanged or riveted copper daggers, bone buttons) appear occasionally in megalithic tombs and more frequently in rock-cut tombs. To sum up, copper daggers with rivets, some of them triangular in shape and quite small and typical of the classic Beaker ware sphere of influence, are very common in rock-cut tombs. However, in the Balearic islands they have not been recorded associated with Beaker ware (which does occur in Early Bronze Age contexts on the mainland). On the other hand, the conical vessel with incised rim appears both in Beaker ware contexts and in megalithic tombs, although it is not characteristic of rock-cut tombs.

As for the navetas, they lack a very characteristic element of the megalithic tombs, namely the conical vessel with incised cordon near the rim; their artefactual assemblages include the repertoire of objects present in other structures as well as their very own elements (razors) and pottery types which could well be ascribed to the Talayotic period.

Given this elaborate framework of associations, a synchronic or a sequential framework might be proposed. The second of them suggests a diachronic sequence of material associations as follows:

1. Beaker wares in open-air settlements (Son FerrandellOleza) and burials in natural caves.

2. Continuity in the use of Beaker wares in settlements and the utilisation of megalithic tombs with Mallorcan incised-ware traditions, perforated bone buttons, archers' wristguards, and undecorated pottery. This would be equivalent in time with the final stages of Beaker ware traditions on the mainland, when typologically late Beaker wares are found in reused megaliths.

3. Rock-cut tombs with the continued use of perforated buttons, archers' wristguards, and riveted daggers, plus the presence of undecorated pottery.

4. The construction of the navetas is accompanied by an important continuity in the presence of earlier gravegoods (buttons, archers' wristguards, and riveted daggers). This can be interpreted as the navetas belonging to earlier traditions dated towards the end of the Chalcolithic and Early Bronze Age. However, if this were indeed the case, it is important to take into account the fact that recurrent elements in previous stages disappeared at the same time, such as the conical vessels with incised rims and, more significantly, the appearance of new artefacts, such as the metal razors which are triangular or semilunar in shape.

Let us now consider the extent to which the radiocarbon dates can clarify the situation regarding our hypothetical sequence of artefact associations.

\section{PRETALAYOTIC RADIOCARBON DATES}

We have collected a total of 27 valid dates which can be tied to archaeological contexts and which span a wide interval from c. $2550-925$ cal. BC (Fig. 1), but are best encapsulated in a sequence which runs from c. $2500-c .1250 \mathrm{cal}$. BC, if we leave aside the extreme ends of the series, especially the most recent one (Son Morell: HAR-2909) ${ }^{2}$ which moves significantly away from the central tendency. In addition, the two recent dates for Son Mas included in the Pretalayotic series, IRPA-1053 and IRPA-976, are somewhat difficult to assess within the context of the cultural expressions we are analysing, as they come from intermediate levels', later than Beaker ware occupations and prior to the construction of the 'sanctuary' (Waldren \& van 


\section{P. V. Castro Martínez et al. RADIOCARBon DATING AND BALEARIC PREHISTORY}

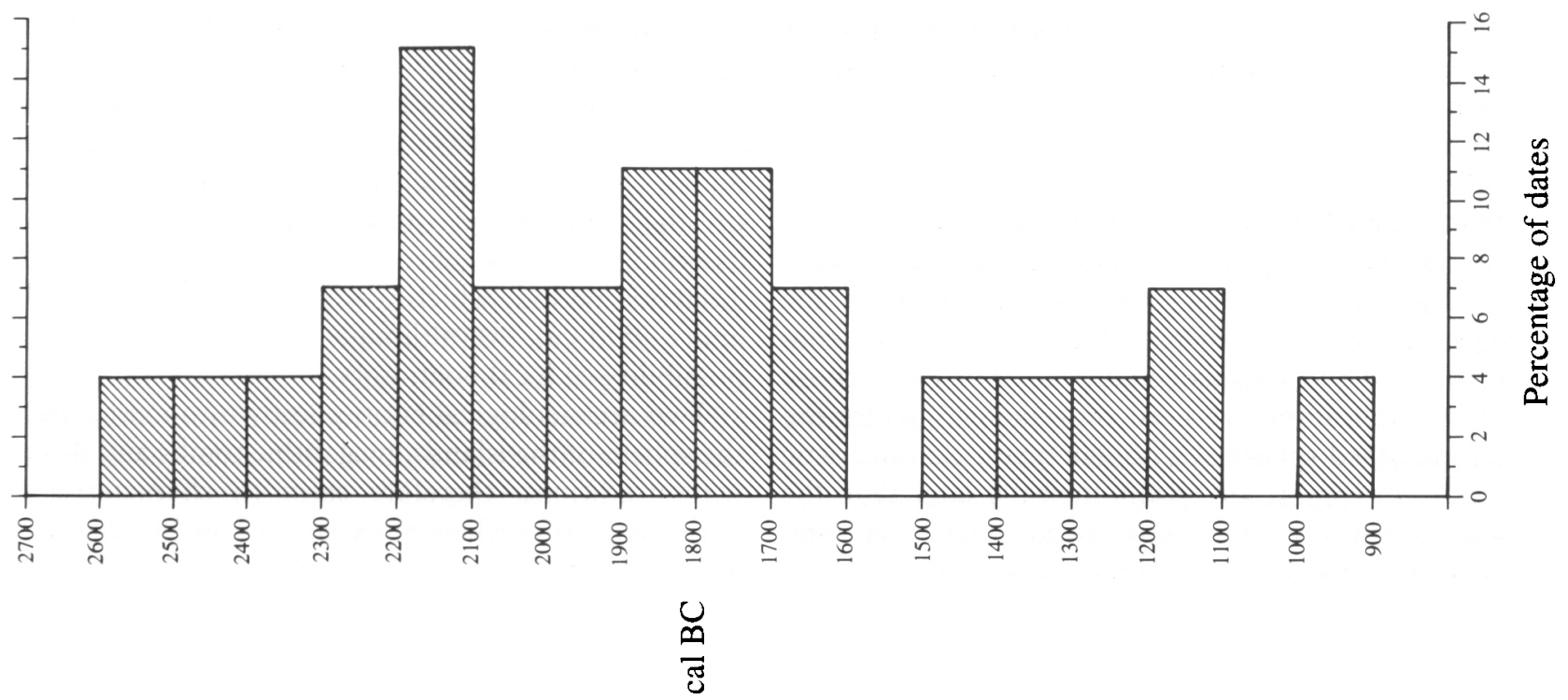

Fig. 1

Pretalayotic radiocarbon date series. Relative frequency distribution of calibrated dates included in the analysis presented in this paper. The values used in Figs 1-4 are those of the median cal. BC at 1 sigma for each calibrated date (see Appendix for full details of all determinations and calibrated ranges)

Strydonck 1992, 15). Consequently we consider it more appropriate to place the end of the Pretalayotic period at $c .1300 / 1250 \mathrm{cal}$. $\mathrm{BC}$, based on the dates for Son Matge (BM-2140R) and the more recent one from the old settlement of Son Ferrandell-Oleza (HAR-3490). However, this limit could be dropped to c. 1150 cal. BC if we take into account the dates from the Mallorcan naviforms of Es Figueral de Son Real (Y-1857, Y-1856) and Son Oms (QL-20), concurrent with the abandonment or reutilisation of these architectural constructions. The latest date for the naveta of Son Morell (HAR-2909) could be evidence for an even later Pretalayotic expression. On the other hand, it could also be that the sample comes from levels which are the result of activities taking place after the site was abandoned.

The main question which we wish to clarify in this section is the chronological position of each of the four possible archaeological entities which come under the heading of Pretalayotic. The chronology of the first, associated with the Beaker ware traditions, is confined to the interval comprising the period c. 2400-1900 cal. $\mathrm{BC}$, as defined by the $\mathbf{1 1}$ dates from the sites of Son Mas, Son Ferrandell-Oleza, Son Matge, and Cova dels Morts-Son Gallard. Balearic Beakers are thus contemporary with later mainland Beaker styles such as those of Palmela, Pyrenaean-Salamó, and the south- east (Castro, Lull \& Micó 1996). Unfortunately, the poor evidence for radio-carbon dating of megalithic tombs does not allow us to adequately assess their temporal relationship with Beaker ware in the Balearic islands. Earlier, we referred to the anomalous character of the dates for Can Sargent (BM-1510, BM-1511), in that they stand outside the accepted chronological framework for megalithism in the Iberian Peninsula and the rest of western Europe as a whole. The third and final radiocarbon date associated with contexts from megalithic tombs (BM-1677), which comes from $\mathrm{Ca} \mathrm{Na}$ Costa in Formentera, must also be discarded, as it was erroneously processed by the British Museum's laboratory and could not be corrected (Bowman et al. 1990, 79).

In spite of these setbacks, if we limit ourselves to chrono-typological considerations and emphasise the fact that elements related to the Beaker ware traditions (such as V-perforated bone buttons, archers' wristguards, and Palmela-type points) are recorded in megalithic contexts, we will have to assume the contemporaneity on the islands of both entities. However, it seems somewhat premature to tackle the question of whether or not we must ascribe them to the same or different human communities. In this respect, the absence of Beaker ware in the Mallorcan and Menorcan tombs seems to suggest the 
existence of two groups influencing the indigenous populations who lived either in open air settlements or in natural caves and buried their dead in natural caves (where it was possible) or in rock-cut tombs.

The majority of the chronological indicators for the rock-cut tombs are typological. In the first place, we have the range of pottery traditionally ascribed to the Pretalayotic period, but this has not yet been the subject of a morphometric study of material from well-defined and well-dated contexts. For the purpose of this publication, we need only point out that the open-mouthed spherical globular types, characteristic of rock-cut tombs, are chronologically later than the conical vessels with incised cordons near the rim, recorded in caves and megalithic tombs, although it is also true that this last type continues in use until c. $1750 \mathrm{cal}$. BC, as attested by the radiocarbon date of Son Marroig (Y-1824). Secondly we must consider, within the area of insular rock-cut tombs, the typology of the riveted daggers. Their formal characteristics are similar to those found in south-east Spain, both in the south of Valencia and in the entire Argaric territory. They are generally associated with the height of the Bronze Age, with dates beginning c. 2250 cal. BC and which can continue until at least c. $1500 \mathrm{cal}$. BC. Nothing in the artefactual repertoire of the rock-cut tombs, therefore, suggests earlier dates and thus they were probably in use after the first Beaker ware elements and megalithic tombs and prior to the appearance of the navetas and the naviforms.

As far as naviforms are concerned, the scant and controversial radiocarbon dates do not clear up the issue of their chronological position. There are four dates relating to these structures from the Mallorcan sites of Es Figueral de Son Real (Y-1857, Y-1856) and Son Oms (QL-20) and from the Menorcan naveta of Son Morell (HAR-2909). The first three dates would correspond with the lowest limit of the chronological interval of the Pretalayotic series, although they ought to be considered more appropriate in the following period (Talayotic) as they were collected from contexts of reutilisation immediately after the structure was abandoned (see Rosselló-Bordoy et al. 1967, 34; Rosselló-Bordoy \& Camps 1972, 134, for Es Figueral; Rosselló-Bordoy 1979, 189, in relation to Son Oms). Consequently, the interval of use must be earlier than c. 1200/1050 cal. BC. As far as the dates for Son Morell are concerned, they could also be affected by the same kind of contextual problems. Beside the problems relating to the verification of these dates, we must not discard the fact that it indicates the continuity of funerary rituals in navetas on the island of Menorca, something which future investigations will have to confirm. In relation to the dating of naviforms and navetas, we reiterate the issue of the typological parallels mentioned earlier, assigning them a chronology transitional to the Talayotic period, which we tentatively place $c .1400$ and c. $900 \mathrm{cal}$. BC, although we do not exclude the possibility of local continuity.

Two archaeological entities known to exist outside the sphere of the islands, megalithic tombs and Beaker ware traditions, therefore seem to characterise an initial stage of settlement expansion on Mallorca and Menorca, as well as on Formentera and possibly also on Eivissa. During this first stage, some architecturally significant open air settlements and other more modest constructions were occupied, as were caves and rock shelters. In a yet-to-be-determined transitional phase between the $3 \mathrm{rd}$ and $2 \mathrm{nd}$ millennia cal. $\mathrm{BC}$, rock-cut tombs would have replaced megalithic tombs as places of funerary deposition, coexisting for a considerable amount of time with caves and natural rock shelters which continued in use as places of habitation or burial. Open air settlements continued in use throughout this temporal interval, as can be deduced from the prolonged use of the old settlement of Son Ferrandell-Oleza. Finally, the navetas constituted the last expression of the ritual of collective inhumations on Menorca.

\section{DEFINING THE TALAYOTIC GROUP}

The archaeological entity traditionally known as the 'Talayotic culture' gets its name from the dry-stone, tower-like structures (talaiots) built with large stones and which are an integral part of the landscapes of Mallorca and Menorca. This distribution and frequency led to an earlier and more intensive investigation of this archaeological expression and has, as a result, become the cornerstone from which the Balearic chronological sequence has been constructed. We should not, therefore, be surprised by the fact that the information available for this group is much fuller and more detailed than the rest of the insular archaeological entities. Unfortunately however, the research undertaken tends to show a marked typological-descriptive orientation.

In spite of the constructional variability between the different talaiots, the majority fall into the 


\section{P.V. Castro Martínez et al. RADIOCARBON DATING AND BALEARIC PREHISTORY}

conically or pyramidally shaped pattern with an interior circular (Sa Canova: Font \& Mascaró 1962), rectangular (Capocorb Vell: Font \& Rosselló-Bordoy 1969; Es Velar: Colominas 1923) or square chamber (Hospitalet, Mallorca: Rosselló-Bordoy 1983), which is reached via a corridor that passes through the talaiot's wall. Furthermore, examples with several juxtaposed chambers are also known (Rafal Roig, Menorca: Manca \& Demurtas 1986) and others have no chambers at all. Another type of talaiot, which is more numerous in Menorca, has only corridors with small cell-like chambers leading off (Ses Font Redones de Baix, Son Vitamina: Plantalamor 1991). The corridor can be rectilinear, curvilinear, or zig-zag; it can also appear as a ramp. Some talaiots have an elevated floor which acts as a kind of look-out post. On Menorca, similar monuments, with an elevated chamber accessible from the outside, have been recorded (Binixíquer: Plantalamor 1991; Sa Torreta: Murray 1934).

The Talayotic settlements are made up of habitation units with straight sided or curving walls enclosing square, rectangular, or kidney-shaped spaces. They usually have columns or pillars designed to sustain a roofing structure and, in their interior, rectangular hearths defined by flat slabs, racks, platforms, benches, and small water cisterns. Typically Menorcan is the house with a central patio, circular in plan (Torelló: Plantalamor 1991) or polygonal (San Agustí Vell Este: Mascaró 1963). At some sites, labyrinthine structures have been recorded which communicate between different sectors of the settlement, as well as salas hipóstilas (hipostyle courts) which may or may not be associated with the settlements (in Mallorca, Els Antigors: Colominas 1923; in Menorca, Binigaus Nou: Plantalamor 1991; Torre d'en Gaumés: Rosselló-Bordoy et al. 1984; Rosselló-Bordoy 1986), with single or multiple stone columns holding up the roofing structure.

The walls which surround the settlements can be irregularly polygonal (Llucamar), made up of rows of parallel stone blocks (Es Pedregar: Colominas 1923) or with uprights resting on flat stone bases (Son Catlar: Plantalamor 1991; S'Illot: Frey \& RossellóBordoy 1964; Frey 1968; 1969; Krause 1977; 1978; Ses Païsses: Lilliu 1960; 1962).

Other architectural elements associated with the Talayotic world are the so-called taulas, exclusive to Menorca. These are apsidal stone precincts enclosing a centrally standing stone monument made up of two large, limestone slabs, one of which is placed vertically to support a horizontal which rests upon it (Torralba d'en Salord: Fernández-Miranda 1978b; Trepucó: Murray 1934; Plantalamor \& Rita 1986; Torre d'en Gaumés: Rosselló-Bordoy et al. 1984). The typology of this group of monuments coincides with those known as sanctuaries, generally quadrangular or apsidal in plan, comprising double-faced walls with irregularly set stone uprights on the outside, earth or small stones between, and rows of medium sized stones on the inside.

In contrast to the situation with the settlements, the funerary world of the Talayotic group lacks clear definition. Talayotic objects have been found in Pretalayotic tombs in Mallorca (Son Sunyer: Veny 1968) and on Menorca (La Cova, Binipati Nou: Plantalamor \& Sastre 1991), but there are none with unequivocal Talayotic burials. As for the practice of inhumation in caves (Son Boronat: Guerrero 1979; Son Maimó: Amorós 1974; Veny 1977) or in open air tomb cemeteries (Son Real, Illot des Porros: Tarradell 1964), we have only been able to verify it as from $c$. $650 / 600$ cal. BC. To sum up, the burial systems employed by the inhabitants of the talaiots remain a problem for research.

If it has been the architectural elements which have formed the basis for the definition of the Talayotic group, the distance between it and the Pretalayotic world is also expressed through other kinds of evidence, such as the pottery. The Talayotic pottery distinguishes itself from earlier traditions in two main ways: the predominance of rectilinear, 'heeled' or slightly convex flat bases and the repeated absence of handles. As a whole, the production of pottery shows a more domestic bias in relation to specific activities which can be recorded in all sorts of structures. The only difference consists of the changing proportions of the types according to the function of the architectural space wherein they appear (large, open mouthed, ovoid storage vessels with two or four vertical protrusions, biconical vessels, sub-cylindrical bowls, medium sized open-mouthed pots, conical vessels, and small pots).

This review of the Talayotic artefact assemblage would not be complete without reference to the abundant macrolithic implements (flat grinding stones, grinders, polishers, mortars, and bowls), which contrast with the scarce flint and metal tools. Metal objects have only been recorded in abundance in Mallorcan deposits (Cas Corraler, Es Corralás de 
Son Bou, Es Mitjá Gran, San Pizá, and Lloseta: Delibes \& Fernández-Miranda 1988). The majority of the recovered pieces echo west European Final Bronze Age products such as flat axes, socketed axes, or palstaves, solid pommel swords, points, and tubular or leaf-shaped spearheads. On the other hand, other elements (chisels, torcs, pectorals, or belts) show greater affinities with north European metallurgy. The first iron objects found in Mallorca (Son Matge) and Menorca (So $\mathrm{Na}$ Caçana, Binicalaf: Plantalamor 1991) are dated to around the beginning of the 8th century $\mathrm{BC}$, although their widespread use does not occur until after $600 \mathrm{cal}$. BC.

In contrast to the relatively full database of this archaeological group, the contributions from research attempting to establish the economic organisation of Talayotic society are somewhat skeletal. The profusion of grinding stones in superficial levels constitutes the only evidence we have to date of the practice of a mixed economy, a practice which has still not been backed up by carpological or palynological analyses. To date, the only published palaeo-economical analyses are those for the sites of Son Fornés (Gasull et al. 1984a), Son Ferrandell-Oleza (Younger Settlement) and S'Illot. The results outline a scenario where the rearing of pigs, cattle, and ovicaprids predominates in subsistence practices. Cattle were consumed as mature adults, which suggests that they were utilised both for traction and for the production of dairy products. On the other hand, the consumption of ovicaprids was centred on the young; as far as the consumption of pig is concerned, there appears to be no particular pattern as to the age at death.

The current theories which seek to explain the origin of Talayotic society can be divided into autocthonous and diffusionist. Those who favour the former stress the local roots of some of the features of the Talayotic world, among which are the cyclopean techniques employed in the architectural constructions and the continuity observed in certain settlements. On the other hand, the diffusionist perspective perceives the new society as being the result of a population influx from Corsica or Sardinia, arguing that talaiots, taulas, and sanctuaries have no precedents in the Balearic islands; the profusion of new types of settlement is seen as reinforcing this argument. Today this second proposal seems more credible, since both the containers (architectural structures) and the archaeological contents (artefacts) underwent highly significant changes between one epoch and the next.
As we shall see, this interpretation could be reinforced by the analyses of the radiocarbon dates.

In this respect, the quantity of Talayotic settlements suggests the occurrence of a considerable population growth, compared with the previous period. To this we may add the fact that a great number of these settlements exceed half a hectare in area and some are as large as 4 ha. This development must be related to a demographic concentration in stable settlements preoccupied with defence and including specific structures dedicated to socio-political (talaiots) or religious (taulas and/or sanctuaries) affairs which affected the whole of society and transcended the domestic domain, These centres, Capocorb Vell and Son Fornés in Mallorca (Gasull et al. 1984a; 1984b; 1984c), Torre d'en Gaumés, Trepucó and Son Catlar in Menorca, would also be associated with one or more secondary settlements, which would also have a talaiot and some houses and would probably define their territories (for example Sabó with respect to Son Fornés and Son Marquet and Son Piris with respect to Son Catlar).

Apart from these important population nuclei, both in Mallorca and Menorca, we can observe a great profusion of settlements, generally comprising isolated talaiots or groups of houses which maintain dispersed populations reliant upon larger centres. Some isolated sanctuaries (Son Mas) or groups of such structures (So Na Caçana: Plantalamor 1986; 1991) probably ensured the population cohesion necessary for the maintenance of the structures of order and power demanded by the Talayotic centres. However we are still far from being able to demonstrate the existence of a relationship between political control and religious institutionalisation, This last feature, however, can be proposed for some structures such as the taulas and some talaiots which are integrated into precincts with more than one towerlike construction (Son Fornés).

\section{THE RADIOCARBON DATES OF THE TALAYOTIC GROUP}

At one time, the dates for the Mallorcan sites of Pula (Son Servera) (P1438) and Son Matge (Y-2667) placed the beginnings of the Talayotic period at c. $1500 \mathrm{BC}$. This early chronology obliged us to propose the idea that the majority of Talayotic expressions were contemporary with the navetas. However, the interpretation of these dates varies if we take into account the data we are dealing with in relation to the 


\section{P.V. Castro Martinez et al. RADIOCARBON DATING AND BALEARIC PREHISTORY}

contexts from which they originated. Pula is still unpublished and the Son Matge rock shelter is inconclusive, firstly because it does not fit the model of an open air Talayotic settlement defined earlier (the date is linked to a funerary context in the cave) and, secondly, because of the exceptional nature of the date obtained for one of the associated artefacts: a solid pommel sword which, in any case, must be adjusted to the chronologies associated with metal objects of the Final Bronze Age. Following this line of chronological analysis, we should set aside these two dates as the starting points of the Talayotic period, and consider the rest of the series as proper Talayotic dates

The first finds from these groups are thus centred around the dates $c .1350-c .1150 \mathrm{cal}$. BC, thanks to the oldest dates from the series of the Mallorcan site of S'Illot (Hv-1716, Hv-1717), between which we insert a date prior to the construction of talaiot $I$ at Son Ferrandell-Oleza (IRPA-1041) and three others from a similar context in the taula at Torralba d'en Salord (QL-1433, HAR-2908b, HAR-2908a). In these initial moments of this archaeological group we must also include the two dates which mark the moment of abandonment of the naviforms of Es Figueral de Son Real. Consequently it would seem more appropriate to place the beginnings of the Talayotic group at around $1200 \mathrm{cal}$. BC. If we accept this date then we must admit to a brief margin of contemporaneity of c. 100 years at $c .1200-1100 \mathrm{cal}$. BC, between the first Talayotic sites and the last naviform sites (Es Figueral, Son Oms, Sa Marina, Son Mercer de Raix) and Pretalayotic ones from Son Matge. This is supported by the controversial date, BM-2140R, obtained from a charcoal sample incorporated into a fragment of construction material (Bowman et al. 1990, 76), the precise context of which is unknown to us. This period of coexistence can also be suggested from some Menorcan navetas, such as Clariana, Binipati Nou, and La Cova.

The synchronicity between the Late Pretalayotic and the beginning of the Talayotic could point towards the contemporary presence on the island of an underlying indigenous element and an exogenous input which would eventually spread throughout the entire Balearic territory (at least on Mallorca and Menorca) in a relatively short space of time. In any event, it seems likely that the local communities quickly incorporated the new material elements. The implications for the interpretation of this episode of contemporaneity can only be reached through a great number of dates which would demarcate with greater precision the strict temporality of the naviforms and the navetas, and then fix more precisely (through the collection of samples in proper Talayotic structural contexts) the beginning of a series of far-reaching transformations in the socio-economic structures of the communities of the Balearic islands.

Towards the end of the 2nd millennium BC (1100-1000 cal. BC), the Talayotic becomes more widely defined on the larger of the Balearic islands. This can be seen in the dates which correspond to the construction of talaiot 4 at Son Ferrandell-Oleza, house 12 at Ses Païsses (Mallorca) or the interior of the taula of Torralba d'en Salord. These structures (Son Ferrandell-Oleza, S'lllot), along with the slightly later examples of talaiot 2 at Son Fornés, talaiot 2 at Son Ferrandell-Oleza, the So Na Caçana complex and the Talayotic houses of S'Illot, continue in use until $c$. 850-800 cal. BC. Following the previous dates, one can still observe (Fig. 2) new and intense settlement dynamics c. 700-600 cal. BC in sites such as Son Fornés, Son Ferrandell-Oleza, Son Mas, and the Menorcan site of Binicalaf.

It is worth pointing out that $c .750-700 \mathrm{cal} . \mathrm{BC}$, a period which appears to be one of stability in the Talayotic settlement, a series of dates associated with a lower funerary level (stratum III) at the Son Matge rock shelter are registered (QL-27, IRPA-811, IRPA803, IRPA-695, IRPA-751, IRPA-676, QL-20, IRPA790, IRPA-752, QL-4, QL-26, QL-6, QL-10). The excavations of this site have revealed burials in quicklime in levels with dates c. 800-600 cal. BC, which suggests the possibility that this characteristically Post-talayotic ritual may have begun in the Talayotic phase. However, this hypothesis will still have to contend with serious historico-archaeological questions. The first attempts to explain the presence of iron objects and the practice of quicklime burials at such early dates, in view of the fact that both elements seem atypical in the material groups of the contemporary Mallorcan communities. The second question is in a sense related to the first, and focuses on the field of historical explanations. If we accept the fact that the previously cited characteristics are indeed Post-talayotic and that these are interpreted on Mallorca as being the result of the influence of Punic colonisation on Eivissa, it is indeed odd to find that Son Matge, an isolated enclave in the north of the island, has traits characteristic of a later period occurring well before their spread throughout the 


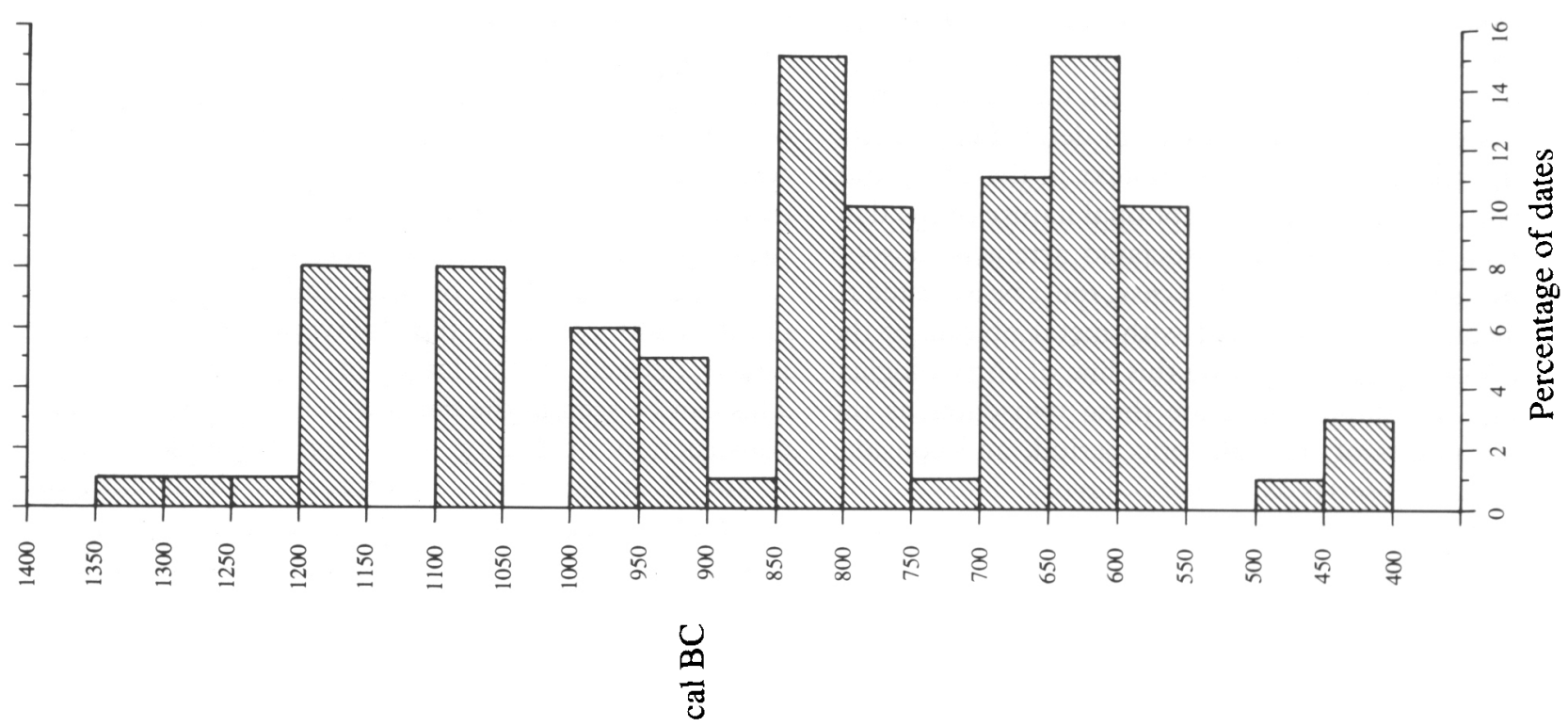

Fig. 2

Talayotic radiocarbon date series. Relative frequency distribution of calibrated dates

island. The uncertainty of the validity of these dates and the lack of sites with comparable evidence place this site temporarily in what we could call a 'bridgehead' in the Post-talayotic.

To the problems of historical explanations derived from these dates are added the difficulties of calibrating the interval which covers the 7 th- 5 th centuries cal. BC. The characteristics of the calibration curve for these centuries force us to approach the synchronic/ diachronic proposals for the dated contexts in this temporal interval with special care. ${ }^{3}$

Figure 3 illustrates the previous comments from the point of view of the temporality of the different types of structures and sites. The initial synchronicity of talaiots and taulas can be observed, although the abundance of dates for the height of this period for the former (primarily due to the complete series for Son Ferrandell-Oleza and Son Fornés) and the lack of dates for the latter (more or less restricted to the dates prior to the construction of Torralba d'en Salord), generate the visible differences in the graphical representations of the percentilic structures of one or the other. This suggests the need for a systematic programme of dating for the taulas which we think will extend over a longer period than the other types of Talayotic sites. In this same graph we can also observe the narrow time span during which the last naviform sites coexisted with the new Talayotic structures, although the dated

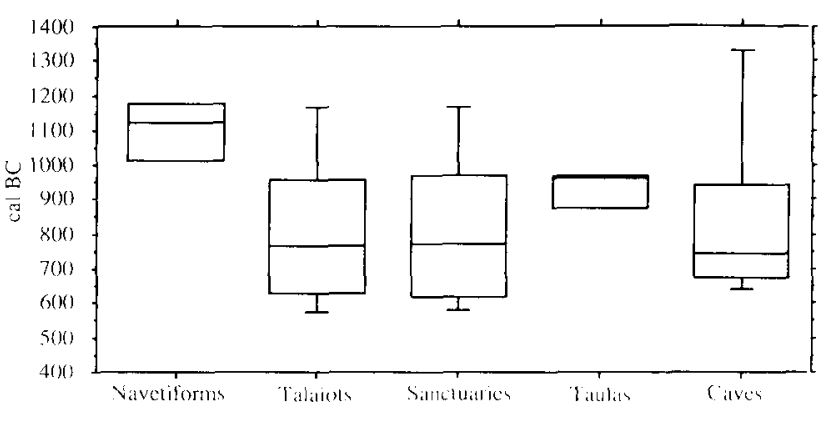

Fig. 3

Talayotic radiocarbon date series. Box plot of the dates corresponding with different types of site

samples correspond with contexts of abandonment or subsequent reutilisation.

On the other hand, from Fig. 3 we can see that, if we adhere to the only extensive evidence of the Son Mas series, the occupation of the horseshoe shaped sanctuaries turns out to be, for the most part, contemporary with that of the talaiots. However, one must bear in mind that the date associated with the beginning of the use of the sanctuary of Son Mas could be placed at c. $900 \mathrm{cal}$. BC if we consider the more recent of the dates related to the series of level II (construction phase) where typically Talayotic pottery is registered (Waldren \& van Strydonck 1992). To the settlement types already referred to, we must add that 


\section{P.V. Castro Martínez et al. RADIOCARBON DATING AND BALEARIC PREHISTORY}

the use of caves, attested by the dates associated with the domestic levels of Son Matge prior to the earliest burial level (QL-986) and Son Muleta (SI-652), eventually became characteristic of the Post-talayotic period,

As from c. $600 \mathrm{cal}$. BC, the talaiot began to lose importance. At this moment in time the two excavated talaiots of Son Fornés and also talaiots 1, 4, and probably 2 of Son Ferrandell-Oleza fell into disuse. At the same time, significant changes can be detected in the use of some sanctuaries (Son Mas) and taulas (Torralba d'en Salord), where Post-talayotic materials subsequently appear.

\section{THE POST-TALAYOTIC SOCIETY OF MALLORCA AND MINORCA.}

The concept of a Post-talayotic period is solely applied to the two main islands, referring to that phase in which the restructuring of settlements and cultural influences from the Levant are recorded. This duality between indigenous and exogenous communities has led to a radically different methodological approach to the establishment of chronological frameworks.

According to the chronologies based on written sources, it is in the mid-7th century cal. BC, that the first Phoenician elements on the island of Eivissa are recorded. Although it would be possible to speculate about the presence of orientalising influences prior to these dates, archaeological research has not refuted this late chronology for the initial colonisation of the island. This is based on the typological analysis of the finds and not on radiocarbon dating, which for the moment has not been applied to any colonial context on the island of Eivissa. On the other hand, we are able to resort to the radiocarbon dates to outline a scenario of the historical dynamics of the islands of Mallorca and Menorca, contemporaneous with the Phoenician-Punic presence on the island of Eivissa.

The previously referred to dual characterisation of this period (as an independent phase - Post-talayotic - or as a continuity of the previous group - Late Talayotic) is such that we find new elements as well as the continuity of others. For the former of these characteristics we must draw attention to the appearance of new architectural models and a new concept of space. Some of the settlements that begin in this phase lack talaiots (Almallutx: FernándezMiranda et al. 1971), while others which were already occupied in the previous period (Son Fornés, S'Illot,
Son Oms, Ses Païsses) construct new domestic quarters, occasionally around talaiots which have fallen into disuse. Added to this continuity of certain settlements is the fact that even constructions of the Talayotic period are reconditioned and reused in a new framework of spatial organisation.

To sum up, this novel Post-talayotic architectural concept is related to the widespread adoption of structures which tend to be quadrangular or rectangular in plan. On Menorca a specific type of construction is developed in the shape of large, round houses. New techniques are also evident in the utilisation of adobe walls. These houses with their new plans are organised next to or around an open patio, established through porch-like areas of columns and pillars, where a well is usually found. This open space also constitutes a novelty in that it is linked with concepts of the organisation of domestic space in use throughout the Mediterranean.

On the other hand, the unique series of Mallorcan structures which, for morphological reasons, have been termed sanctuaries in the archaeological literature, are characteristic of this phase. These are quadrangular in plan, with walls of medium sized blocks of right angled stones (Son Oms, Almallutx, Els Antigors de Ses Salines: Colominas 1923). The existence of central stones, like trilithic columns, has been noted (S'Illot, Es Pedregar, Son Oms: Colominas 1923).

As for Menorca, the types of construction known as taulas are reused. All these buildings have been interpreted as cult places (eg. Mascaró 1968) as a consequence of the discovery in some cases of statuettes of warriors or bulls (Roca Rotja or Costitx in Mallorca, Torralba d'en Salord in Menorca). At the same time, vessels or deposits containing goat, pig, or cattle bones have also been found and are considered to be the remains of offerings.

Although few studies have been carried out, the data seem to suggest that we are also witnessing certain changes in farming practices. Agricultural activities are intensified and thus provide the basis for an accumulation of surpluses which allowed island communities to join in the trading networks of the Mediterranean, especially through the island of Eivissa and, later on, through contact with the Roman world.

These transformations can be related to the need for a restructuring of the landscape. Three avenues have been proposed for this process of change. In the 
first place, an increase in the occupation of extramural areas is recorded and consequently an enlargement of the settlements, and probably a rise in population. Another aspect would be the increase in the efficiency of agricultural production, evident in the appearance of a greater number of utensils associated with the processing of cereals (grinding stones and mortars) and an increase in the kind of pottery vessels undoubtedly designed for the storage and processing of these products. This scenario would have favoured the specialisation of settlements in accordance with their territorial situation and thus their economic potential. And so, in Mallorca, the inland communities would be differentiated from those located in the mountains or the coastlines. Finally, a development in exchange between communities is attested by the appearance of imported colonial products such as amphorae for the storage of oil and wine, wheelthrown pottery, and iron objects.

The Punic presence on the island of Mallorca would have already increased progressively in two ways during the 6th century BC (Guerrero 1981; $1984 a ; 1984 b ; 1985 ; 1987)$. The recruitment of mercenaries, either through the occupation of certain enclaves or by resorting to mechanisms of coercion, cannot be excluded. Coastal settlements, especially those situated on small islets (Illot dels Porros, $\mathrm{Na}$ Guardis, Illot des Frares, Illot de Na Galera) seem to respond to a strategic role, associated with the colonial control of local commerce. They would thus constitute the central focus of the Ebusitanian colonisation of Mallorca, showing its influences from the 4th century BC in local, coastal settlements, such as Es Trenc, and especially Turó de Ses Beies (Santa Ponsa), which was probably a centre for the storage and redistribution of colonial products throughout the central parts of the island during the 3rd century $\mathrm{BC}$. The network of coastal settlements on islets shows a similar pattern to the Phoenician occupation of southern Spain, although in this case in relation to the interests of the Punic state, mediated by Eivissa. In any event, the colonial dynamics of Mallorca and Menorca do not correspond to one of territorial exploitation, which would still continue to be in the hands of local populations.

Right from the first systematic studies concerned with Balearic prehistory until the present day, the interpretation of the Post-talayotic has been characterised by the assimilation of the material changes of the Talayotic group to a process of acculturation, the result, in particular, of the colonial presence on Eivissa and throughout the west Mediterranean (Maluquer 1947; Amorós 1952; Rosselló-Bordoy 1973; 1979; Fernández-Miranda $1978 \mathrm{a}$; Waldren 1982; 1986). Interpretations of Posttalayotic society have paid special attention to the characteristics of this process, fundamentally through ideological inferences based on data recovered from funerary or cultural contexts. As with the sanctuaries, the information provided by the necropoli has been interpreted as a fusion between two different societies (Punic and local), in that certain elements (vitreous paste necklaces, small bells, or small votive jugs) are interpreted as being adopted directly from the Punic world.

It is precisely during the Post-talayotic period that, unlike the preceding epoch, a large diversity of funerary practices is apparent (Rihuete 1992). One of the most common funerary practices is the system of inhumation in quicklime, usually in rock shelters or natural caves (Son Bosc and Ses Copis: Enseñat Enseñat 1981) or rock-cut tombs (S'Alova: ibid.; Cometa des Morts: Veny 1947; 1981; 1983), although this also occurs in certain settlements (Son Fornés). Inhumations in urns or wooden stretchers or sarcophagi are also known (Son Maimó: Amorós 1974; Veny 1977, Son Boronat: Guerrero 1979), which on occasion take on the form of cattle (Avenc de Sa Punta: Pons i Homar 1988). The coexistence of simple inhumations and those carried out in quicklime is documented in the Mallorcan necropolis of Son Real (Tarradell 1964), characterised by funerary containers that mimic on a smaller scale the prototypes of the talaiots and navetas and which have no counterpart in the rest of the Balearic islands. Lastly, the existence of urn cemeteries is also known, usually cremations placed in containers excavated into the local bedrock or marés (Son Oms: Rosselló-Bordoy \& Guerrero 1983), although these are chronologically more recent.

As for the finds, there is also a great diversity of products and raw materials. Together with ceramic, bone, copper, and bronze traditional objects, we find a great profusion of objects manufactured with vitreous paste, iron, and lead. Amongst the characteristically funerary items of this phase it is worth mentioning the Punic crockery, necklaces, and traditional ornaments, the so-called bone 'tampons' (Waldren 1992), and the metal zoomorphic horns and figurines (normally of cattle or birds). 


\section{P.V. Castro Martinez et al. RADIOCARBON DATING AND BALEARIC PREHISTORY}

The evidence of the differences between burials, both in the treatment of the corpse and the architectural structures, as well as the quantity and quality of the grave-goods, could be related to the emergence of aristocracies in the communities of the islands. In this way, we find a funerary architecture and a collection of exceptionally rich grave-goods in the necropolis of Son Real, far removed from what appears to be taking place in other funerary groups.

It has even been suggested that Post-talayotic communities were highly militarised, given the slingshot mercenaries often cited in classical sources. This society would thus function on the basis of kin relationships under the domain of a system of leadership. In our opinion, the colonial relationships established through the Punic world, especially in the areas of direct colonisation, probably promoted certain local groups to an aristocracy and, consequently, heightened socio-economic differences. Nevertheless, the distinctive impact of colonial relations between the various islands seems fairly conclusive and the proposed collapse of these local structures will have to be clarified by future research.

\section{THE RADIOCARBON SEQUENCE OF THE POST-TALAYOTIC PERIOD}

The radiocarbon dates associated with Post-talayotic contexts show a slight numerical decrease in relation to the Talayotic group. For the period which encompasses the final stages of the Talayotic and the end of the first millennium BC in Mallorca and Menorca, we have a sequence of 32 valid dates (Fig. 4). This minor interest in physico-chemical methods of dating is undoubtedly partly due to the greater weight of archaeological chronologies based on typological parallels used in research on the late 1st millennium $B C$ in the Balearic islands. In spite of the limited number of dates and their concentration in a few sites, we will attempt to outline the chronology of Post-talayotic transformations, though this time in tune with the socio-economic dynamics of the local populations of Mallorca and Menorca.

The dates which are available to us encompass a temporal span from the beginning of the 7 th century cal. BC until the Christian era, with the date of occupation of the fully Romanised settlement of Son Fornés (UAB-8). However, in order to establish the beginning of what we might term the colonial impact on the larger of the Balearic islands we face two very different problems.
On the one hand we must remember the alreadymentioned controversial dates for Son Matge, labelled as Post-talayotic due to the presence of material goods closely associated with this period, which takes us from 800-600 cal. BC (QL-27, QL-20, QL-4, QL-6, $\mathrm{QL}-10)$. On the other hand, we must not forget that radiocarbon dates located in the $800-400$ cal. BC interval are particularly problematic, because of the characteristics of the calibration curve. If we dispense with the dates for Son Matge, the presence of Posttalayotic elements does not overlap with the final dates of the Talayotic group. This is illustrated by the earliest Post-talayotic contexts which do not suffer from problems of assignation or context and occur in the $450 / 400$ cal. BC interval, both in terms of settlements (Torralba d'en Salord: BM-2003R; Son Mas: KIK-3/UtC-1003; Son Fornés: UAB-12) and funerary complexes (Son Boronat: BM-1518, BM1517; Son Maimó: QL-144). For the time being, this absence of contemporary Talayotic and Post-talayotic contexts seems to point towards a speedy and generalised acquisition of the Post-talayotic material assemblage as well as the associated socio-economic and ideological changes.

However, the main body of dates for this period is concentrated c. 300-200 cal. $\mathrm{BC}$, a time when the urban space of the three sites which offer us a series of dates (Son Fornés, Son Mas, and Torralba d'en Salord) is enlarged and renovated. From this we can propose a second stage in the development of Posttalayotic society, with its moment of greatest expansion occurring in the 3 rd century cal. BC. It will be necessary to back this up with a more extensive and intensive programme of dating. In this way, the degree of articulation of these possible Post-talayotic phases with the changes brought about by the dynamics of colonialism would allow us to evaluate the importance of exogenous and endogenous elements in the socio-economic transformations on the islands.

If we compare this model of Post-talayotic settlement with the temporality of the funerary expressions associated with this period, we can, on the one hand, confirm the continuity until the end of the 2nd century cal. BC of inhumations in quicklime at Son Matge and Son Fornés, and on the other we can document new forms of burials (inhumations in wooden coffins and inhumations practised inside the settlement). The new funerary practices, curiously, show a considerable chronological span: burials in 


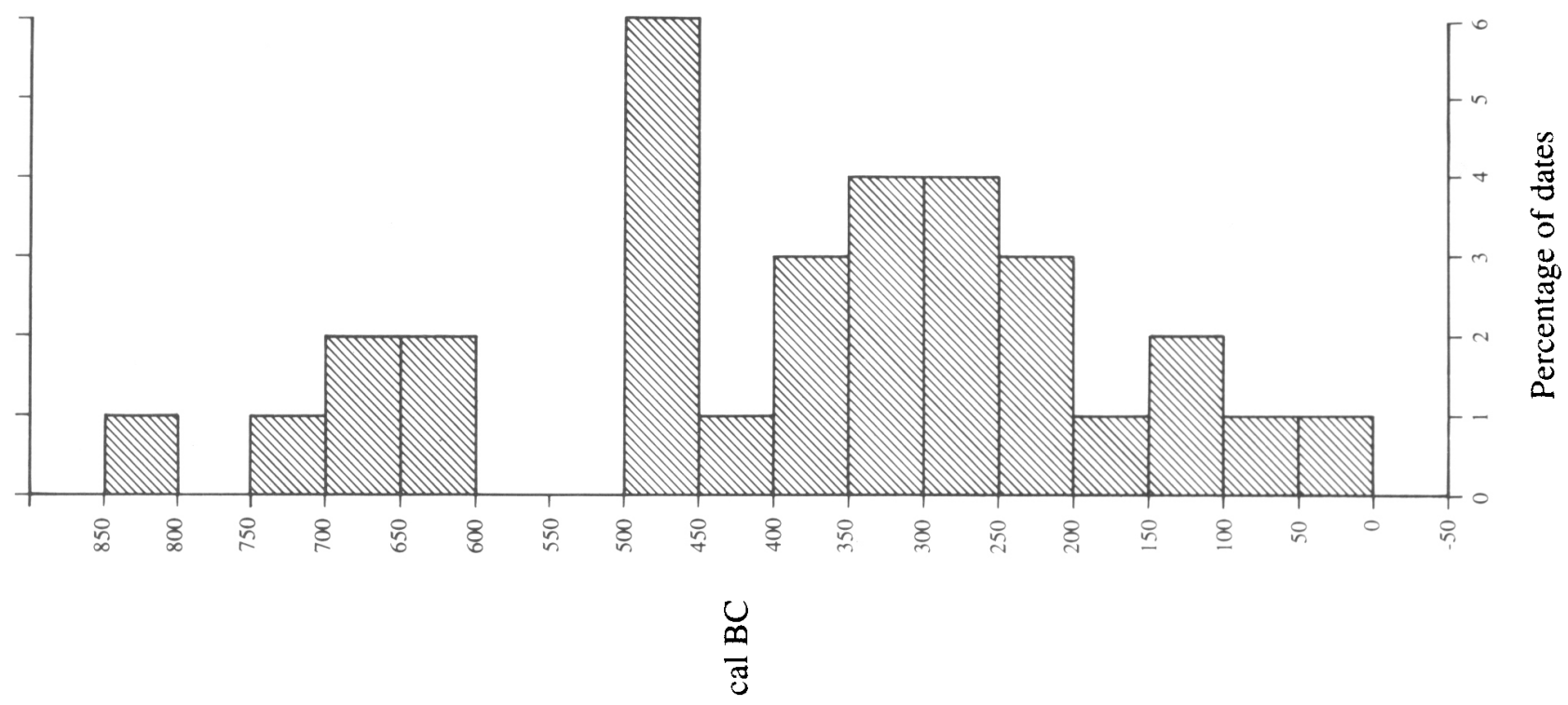

Fig. 4

Post-talayotic radiocarbon date series. Relative frequency distribution of the calibrated dates

coffins or sarcophagi in the first stages of the Posttalayotic period (Son Boronat, Avenc de Sa Punta), while the two inhumations of Son Fornés occur in the 2nd century cal. BC.

\section{CONCLUSION}

At the beginning of this paper we referred to the fact that results of analyses of radiocarbon dates of the Balearic islands can only offer an initial outline for the restructuring of a prehistoric sequence. All in all, we believe that certain explanatory hypotheses concerning the history of the islands until the Christian era require the explicit support of a programme of radiocarbon dates. The temporal divisions of possible Pretalayotic groups, the characterisation and the transitional dynamics of the Pretalayotic-Talayotic and Talayotic-Post-talayotic, the development of local settlements following the colonial impact or the necessity to articulate the prehistoric sequence of all of the islands of the Balearics, including the Pitiussae (Ibiza and Formentera), are problems which will only be solved through independent temporal references such as the ones offered by the calibration of radiocarbon dates.

Acknowledgements: The authors want to thank Dylan Cox for the English translation of the text and Bob Chapman and Gay Butt for revising it and preparing it for publication in this journal. Simón Gornés has also read the manuscript, providing valuable comments and suggestions, but only the authors should be considered responsible for any possible errors or omissions.

\section{ENDNOTES}

${ }^{1}$ Information on two new dates (Cotaina, Menorca) reached us when this paper was practically finished. Although we refer to them in certain sections of this publication, we have not been able to include them in the graphs. The dates are as follows: IRPA-1046A (4600 $\pm 60 \mathrm{BP})$, and IRPA-1046B $(4450 \pm 60 \mathrm{BP})$, obtained from samples collected from the interior of a Menorcan naveta, whose calibration gives us the dates of $950-890 \mathrm{cal} \mathrm{BC}$ and $780-450 \mathrm{cal} \mathrm{BC}$ respectively. Further new dates which arrived too late for inclusion in this paper came from Cova d'es Carritx, Montplé and Binipatí Nou (Hedges et al. 1996, 409-10), and Cotaina d'En Carreres, Cales Coves, Binigaus, and Torralba d'En Salord (Van Strydonck et al. 1995, 28-9) in Menorca, and Son Ferrandell Oleza and Son Mas (van Strydonck et al. 1995, $22-5,29$ ) in Mallorca.

${ }^{2}$ Son Ferrandell-Oleza has a date nominally ascribed to the Pretalayotic (BM-2297R), but its interval is far removed from the interval marked out by the main body of the radiocarbon series.

${ }^{3}$ The calibration curve shows segments in which the scarcity of inclination implies that events which took place in temporal intervals of differences up to a century appear as contemporaneous in the results of the radiocarbon dates. The most problematic segment is precisely the one which fluctuates between $800-400$ cal. BC (Bowman et al. 1990, 57). 


\section{P.V. Castro Martínez et al. RADIOCARBON DATING AND BALEARIC PREHISTORY}

\section{BIBLIOGRAPHY}

Almagro Gorbea, M. 1970. Las fechas del C-14 para la Prehistoria y la Arqueología Peninsular. Trabajos de Prehistoria 27, 9-44.

Alonso, J., Cabrera, V., Chapa, T. \& Fernández-Miranda, M. 1978. Indice de fechas arqueológicas de C-14 para España y Portugal. In $\mathrm{C}^{14}$ y Prehistoria de la Península Ibérica. Fundación Juan March. Madrid: Serie Universitaria 77, 154-83.

Amorós, L. 1952. La Edad del Bronce en Mallorca. Palma de Mallorca: Panorama Balear.

Amorós, L. 1974. La cueva sepulcral prerromana de Son Maimó en el término municipal de Petra (Mallorca). VI Symposium de Prehistoria Peninsular. Prehistoria $y$ Arqueología de las Ilas Baleares, 137-79. Barcelona: Publicaciones Eventuales 24.

Anglada, J. 1976. Estudio de una naveta de habitación de Son Mercer de Baix-Menorca. Mayurqa 15, 271-89.

Bowman, S.G.E., Ambers, J.C. \& Leese, M.N. 1990. Reevaluation of British Museum radiocarbon dates issued between 1980 and 1984. Radiocarbon 32(1), 59-79.

Camps, J. \& Rosselló-Bordoy G. 1970. Fechas absolutes en lo talayótico mallorquin. XI Congreso Nacional de Arqueología, 850-4.

Cantarellas, C. 1972a. Cerámica incisa en Mallorca. Palma de Mallorca: Caja de Ahorros y Monte de Piedad de las Baleares.

Cantarellas, C. 1972b. Excavaciones en Ca Na Cotxera (Muro, Mallorca). Noticiario Arqueológico Hispánico 1, 179-226.

Carbonell, E., Mora, R., Pons-Moya, J. \& Coll, J. 1981. La indústria en sílex del jaciment a l'aire lliure de la zona del Rafal des Porcs-Cova des Drac (Santanyí, Mallorca). Endins 8, 75-80.

Castro, P.V., Gili Suriñach, S., Lull, V., Micó, R. \& Rihuete, C. 1996. Jaciments datats pel metode del $\mathrm{C}^{14}$ calibrat. In E. Junyent (ed.), Historia, Societat $i$ Cultura dels Paisos Catalans. I Prehistoria. Etat Antiga i Mitgana, 410-17. Barcelona: Enciclopedia Catalana.

Castro, P.V., Lull, V. \& Micó, R. 1996. Cronologia de la Prehistoria Reciente de la Peninsula Ibérica y Baleares (c. 2800-900 cal. ANE). Oxford: British Archaeological Report S652.

Chapman, R.W., Strydonck, M. van \& Waldren, W.H. 1993. Radiocarbon dating and Talayots: the example of Son Ferrandell-Oleza. Antiquity 67, 108-16.

Colominas, G. 1923. L'Edat del Bronze a Mallorca: les investigacions de l'Institut (1915-1920). Anuari de l'Institut d'Estudis Catalans VI, 555-73.

Costa, B. \& Fernández Goméz, J.H. 1992. Les Illes Pitiusses: de la prehistória a la fin de l'época púnica. In Rosselló-Bordoy, G. (ed.), La Prehistória de les Illes de la Mediterrània Occidental. X Jornades d'Estudis Històrics locals, 277-355. Palma de Mallorca: Museu de Mallorca.

Delibes, G. \& Fernández-Miranda, M. 1988. Armas y Utensilios de Bronce en la Prehistoria de las Islas Baleares. Valladolid: Studia Archaeologica 78.
Ense, C. 1971 Excavaciones en el navetiforme Alemany, Magalluf (Mallorca). Noticiario Arqueológico Hispánico 15, 39-73.

Enseñat Enseñat, C. 1991. Las Cuevas Sepulcrales Mallorquinas en la Edad del Hierro. Madrid: Excavaciones Arqueológicas en España, 118.

Fernández Goméz, J.H. 1977. Ultimos descubrimientos prehistóricos en la isla de Formentera (Baleares). XIV Congreso Nacional de Arqueología (Vitoria, 1975), 471-9.

Fernández Gorméz, J.H., Plantalamor, Ll. \& Topp, C. 1976. Excavaciones en el sepulcro megalítico de $\mathrm{Ca} \mathrm{Na}$ Costa (Formentera). Mayurqa 15, 109-38.

Fernández Goméz, J.H., Plantalamor, Ll. \& Topp, C. 1988. Excavaciones en el sepulcro megalítico de $\mathrm{Ca} \mathrm{Na}$ Costa (Formentera). Ibiza: Trabajos del Museo Arqueológico de Ibiza 19.

Fernández Goméz, J.H. \& Topp, C. 1984. Prehistoric activities in the Pitiussae islands. In W.H. Waldren et al. (eds) $1984,763-84$.

Fernández-Miranda, M. 1978a. Secuencia Cultural de la Prehistoria de Mallorca. Madrid: Biblioteca Praehistorica Hispana 15.

Fernández-Miranda, M. 1978b. Torralba d'en Salord (Alayor, Menorca). XV Congreso Nacional de Arqueologia, 259-72.

Fernández-Miranda, M. Enseñat, C. \& Enseñat, M. 1971. El Poblado de Almallutx (Escorca, Baleares). Madrid: Excavaciones Arqueológicas en España 73.

Fernández-Miranda, M. \& Waldren, W.H. 1974. El abrigo de Son Matge (Valldemossa) y la periodización de la prehistoria mallorquina mediante los análisis de C14. Trabajos de Prehistoria 31, 297-304.

Fernández-Miranda, M. \& Waldren, W.H. 1979. Periodificación cultural y cronología absoluta en la prehistoria de Mallorca. Trabajos de Prehistoria 36, 349-77.

Florit, G. 1966. Consideraciones sobre la forma extema original de la naveta de Es Tudons. Revista de Menorca 54, 56-64.

Font, B. \& Mascaró, J. 1962. Tipología de los Monumentos Megalíticos de Mallorca. Palma de Mallorca: Colección Talaiot.

Font, B. \& Rosselló-Bordoy, G. 1969. El Poblado Prehistórico de Capocorb Vell (Lluchmayor). Lluchmayor: Ayuntamiento de Lluchmayor.

Frey, O.H. 1968. Zweiter Bericht über die Untersuchungen in der Talayot-siedlung von S'Illot (San Lorenzo, Mallorca). Madrider Mitteilungen 9, 63-75.

Frey, O.H. 1969. Untersuchungen zu den Kleinfunden aus S'Illot (Mallorca). Madrider Mitteilungen 10, 117-18.

Frey, O.H. \& Rosselló-Bordoy, G. 1964. Eine Talayotsiedlung bei S'Illot, Mallorca. Madrider Mitteilungen 5, $55-71$.

Gasull, P., Lull, V, \& Sanahuja, Ma. E. 1984a. Son Fornés I. La Fase Talayótica. Ensayo de Reconstrucción Socioeconómica de una Comunidad Prehistórica de la Isla de Mallorca. Oxford: British Archaeological Report S209. 


\section{THE PREHISTORIC SOCIETY}

Gasull, P., Lull, V. \& Sanahuja, Ma. E. 1984b. Estudio comparativo de los talaiots no 1 y 2 de Son Fornés (Montuiri, Mallorca). In W.H. Waldren et al. (eds) 1984, 1239-57.

Gasull, P., Lull, V. \& Sanahuja, Mª.E. 1984c. La habitación no. 5 de Son Fornés (Montuiri-Mallorca). Modelo de una vivienda talayótica. In W.H. Waldren et al. (eds) 1984, 1269-98.

Gili Suriñach, S., Lull, V. \& Rihuete, C. 1996. Les Illes Balears dels origens al segle VII cal ANE. In E. Junyent (ed.), Historia, Societat i Cultura dels Paisos Catalans. I. Prehistoria, Etat Antiga i Mitgana, 196-214. Barcelona: Enciclopedia Catalana.

Gomez Bellard, C. \& San Nicolás Pedraz, Ma. P. 1988. La prehistoria de Ibiza y Formentera: estado actual de la investigación. Trabajos de Prehistoria 45, 201-28.

González Marcén, P., Lull, V. \& Risch, R. 1992. Arqueologia de Europa, 2250-1200 A.C. Una introducción a la Edad del Bronce. Madrid: Síntesis.

Gornés, S., Gual Cerdo, J. Ma., Lopez Pons, A. \& Nicolas, J.C. 1992. Nous monuments funeraris del món pretalaiòtic de Menorca. In Rosselló-Bordoy, G. (ed.) La Prehistòria de les Illes de la Mediterrània Occidental. X Jornades d'Estudis Històrics Locals, 419-52. Palma de Mallorca: Museu de Mallorca.

Guerrero, V. Ma. 1979. El yacimiento funerario de Son Boronat (Calvià-Mallorca). Bolletí de la Societat Arqueològica Lulliana 830-1, 1-50.

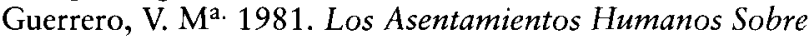
los Islotes Costeros de Mallorca. Palma de Mallorca: Trabajos de Museo de Mallorca 31.

Guerrero, V. Ma. 1984a. Asentamiento Púnica de Na Guardis. Madrid: Excavaciones Arqueológicas en España 133.

Guerrero, V. Ma. 1984b. La Colonización Púnico-ebusitana de Mallorca. Estado de la Cuestión. Ibiza: Trabajos del Museo Arqueológico de Ibiza, 11.

Guerrero, V. Ma. 1985. Indigenisme i Colonització Púnica a Mallorca. Palma de Mallorca: Ayuntamiento de Ses Salines.

Guerrero, V. Ma 1986. El Elemento Púnico en la Cultura Talayótica. Mahon: Trabajos del Museo de Menorca 5.

Guerrero, V. Ma. 1987. La Colònia de Sant Jordi (Mallorca). Estudis d'Arqueologia i Epigrafia. Palma de Mallorca: Publicacions del Centre d'Estudis Gabriel Alomar.

Hedges, R.E.M., Pettitt, P.B., Bronk Ramsey, C. \& Klinken, G.J. van. 1996. Radiocarbon Dates from the Oxford AMS system: Archaeometry datelist 22. Archaeometry $38,391-415$.

Krause, G. 1977. Bericht über die vierte Grabungskampagne in der Talayotsiedlung von S'Illot (San Lorenzo, Mallorca). Madrider Mitteilungen 18, 30-2.

Krause, G. 1978. Bericht über die fünfte Grabungskampagne in der Talayotsiedlung von S'Illot (San Lorenzo, Mallorca). Madrider Mitteilungen 19, 77-88.

Lilliu, G. 1960. Primi scavi del villaggio talaiotico di Ses Païsses (Artà-Maiorca) (Missione archeologica italiana, aprile maggio 1959). Revista dell'Istituto Nazionale d'Archeologia e Storia dell'Arte 9, 5-73.
Lilliu, G. 1962. Cenno sui piu recenti scavi del villaggio talaiotico di Ses Païsses ad Artà-Maiorca (Baleari). Studi Sardi 18, 22-52.

Maluquer, J. 1947. La Edad del Bronce en las Islas Baleares. In Menéndez Pidal, R. (ed.), Historia de España. Madrid: Espasa-Calpe.

Manca, S. \& Demurtas, S. 1986. Di un Tipo Architettonico Mediterraneo: Talaiot Rafal Roig (Minorca). Cagliari: Selargius.

Mascaró, J. 1963. El talaiot de San Agustí Vell. Cuadernos de Tramuntana, 3-19.

Mascaró, J. 1968. Prebistoria de las Islas Baleares. Palma de Mallorca: Gráficas Miramar.

Mook, W.G. 1986. Business meeting: recommendations/ resolutions adopted by the twelfth International Radiocarbon Conference. Radiocarbon 28, 799.

Murray, M.A. 1934. Cambrldge Excavations in Menorca, Sa Torreta. London: B. Quaritch.

Pearson, G.W. \& Stuiver, M. 1986, High-precision Calibration of the radiocarbon time scale, $500-2500 \mathrm{BC}$. Radiocarbon 28, 839-62.

Pearson, G.W., Becker, B. \& Qua, F. 1993. High-precision ${ }^{14} \mathrm{C}$ measurement of German and Irish oaks to show natural ${ }^{14} \mathrm{C}$ variations from 7890 to 5000 BC. Radiocarbon 35, 93-104.

Pericot, L. 1975. Las Islas Baleares en los Tiempos Prehistóricos. Barcelona: Destino.

Plantalamor, Ll. 1976. La naveta Clariana. Estudio de los materiales. Mayurqa 14, 231-45.

Plantalamor, Ll. 1976/77. Algunas consideraciones sobre los sepulcros megalíticos de Menorca. Sautuola 2, 157-73.

Plantalamor Ll. 1977. El sepulcro megalítico de Binidalinet (Mahón, Menorca). XIV Congreso Nacional de Arqueología (Vitoria 1975), 479-2.

Plantalamor, Ll. 1986. El Santuado de So Na Caçana y las Relaciones con el Mediterráneo Central y Oriental. Cagliari: Selargius.

Plantalamor, Ll. 1991. L'Arquitectura Prehistórica $i$ Protohistórica de Menorca i el seu Marc Cultural. Maó: Treballs del Museu de Menorca 12.

Plantalamor, Ll. 1992. La prehistória i protohistória de Menorca. Estat actual de la qüestó. In Rosselló-Bordoy, G. (ed.), La Prehistória de les Illes de la Mediterránia Occidental. X Jornades d'Estudis Histórics Locals, 83-130. Palma de Mallorca: Museu de Mallorca.

Plantalamor, Ll. \& Anglada, J. 1981. Excavacions a les navetes d'habitació de Clariana (Ciutadella, Menorca). Fonaments 1, 205-8.

Plantalamor, Ll., Anglada, J. \& Rita, C. 1977. Avance sobre las excavaciones en las navetas de habitación de Clariana (Menorca). XIV Congreso Nacional de Arqueologia (Vitoria 1975), 483-86.

Plantalamor, Ll. \& López Pons, A. 1983. La naveta accidental de Biniac-La Argentina (Alayor, Menorca), Noticiario Arqueológico Hispánico 15, 359-82.

Plantalamor, Ll. \& Rita, C. 1979. Arqueologia III y IV. In Enciclopedia de Menorca, 213-52. Cuitadella: Obra Cultural Balear. 


\section{P.V. Castro Martinez et al. RADIOCARBON DATING AND BALEARIC PREHISTORY}

Plantalamor, Ll. \& Rita, C. 1982. Tres cuevas de la Edad del Bronce en la zona occidental de Menorca. Ampurias 44, $1-16$.

Plantalamor, Ll. \& Rita, C. 1984. Formas de población durante el II y I milenio BC en Menorca: Son Mercer de Baix, transición entre la Cultura Pretalayótica y Talayótica. In W.H. Waldren et al. (eds) 1984, 797-826.

Plantalamor, LI. \& Rita, C. 1986. Guia Arqueológica del Poblat de Trepucó. Ciutadella: Consell Insular de Menorca.

Plantalamor, LI. \& Sastre, J. 1991. Excavació d'urgència de la naveta de Binipati Nou (Ciutadella). Meloussa 2, 163-72.

Pons i Homar, G. 1988. Sarcófagos tauromorfos en la protohistoria mallorquina. Revista de Arqueologia 83, 32-9.

Pons-Moyà, J. \& Coll, J. 1984. Les industries lítiques dels jaciments a l'aire lliure de la zona de Santanyí (Mallorca). In W.H. Waldren et al. (eds) 1984, 841-58.

Rihuete, C. 1992. Sistemas de Enterramiento en Mallorca entre c. siglos. VI-I ane. Tesis de Licenciatura (unpublished), Universitat Autónoma de Barcelona, Bellaterra.

Rita, C. 1988. The evolution of the Minorcan Pretalayotic culture as evidenced by the sites of Morellet and Son Mercer de Baix. Proceedings of the Prehistoric Society 54, 241-7.

Rosselló-Bordoy, G. 1965. Excavaciones en el Círculo de Son Bauló de Dalt. Madrid: Excavaciones Arqueológicas en España 51.

Rosselló-Bordoy, G. 1966. Las navetas de Mallorca. Studi Sardi 19.

Rosselló-Bordoy, G. 1973. La Cultura Talayótica en Mallorca. Palma de Mallorca: Cort.

Rosselló-Bordoy, G. 1979. La Cultura Talayótica en Mallorca (2nd ed.). Palma de Mallorca: Cort.

Rosselló-Bordoy, G. 1983. El Poblado Prehistórico de Hospitalet Vell (Manacor). Palma de Mallorca: Institut d'Estudis Baleàrics.

Rosselló-Bordoy, G. 1986. El Poblado Prehistórico de Torre d'en Gaumés (Alaior). Palma de Mallorca: Institut d'Estudis Baleàrics.

Rosselló-Bordoy, G. \& Camps, J. 1972. Excavaciones en Es Figueral de Son Real. Noticiario Arqueológico Hispánico 1 .

Rosselló-Bordoy, G. \& Camps, J. 1976. Excavaciones en Canyamel, Cap de Pera (Mallorca). Noticiario Arqueológico Hispánico 5, 235-51.

Rosselló-Bordoy, G. \& Frey, O.H. 1967. Els Closos de Can Gaià. Palma de Mallorca: Gráficas Miramar.

Rosselló-Bordoy, G. \& Guerrero, V.M ${ }^{\mathrm{a}}$. 1983. La necrópolis infantil de Cas Santamarier (Son Oms) (Palma de Mallorca). Noticiario Arqueológico Hispánico 15, 406-48.

Rosselló-Bordoy, G., Plantalamor, Ll. \& Lopez Pons, A. 1980. Excavaciones arqueológicas en Torre d'en Gaumés (Alayor, Menorca). I. La sepultura megalítica de Ses Roques Llises. Noticiario Arqueológico Hispánico 8, 71-138.
Rosselló-Bordoy, G., Plantalamor, Ll. \& Soberats, F. 1984. Excavaciones arqueológicas en Torre d'en Gaumés (Alayor, Menorca). El recinto de la Taula y el sistema de recogida de aguas (campañas 1974, 1975 y 1977). Noticiario Arqueológico Hispánico 19, 103-97.

Rosselló-Bordoy, G. \& Waldren, W.H. 1973. Excavaciones en el abrigo del bosque de Son Matge (Valldemosa, Mallorca). Noticiario Arqueológico Hispánico: prehistoria 2, 1-86.

Rosselló-Bordoy, G., Waldren, W.H. \& Kopper, J.S. 1967. Análisis de Radiocarbono en Mallorca. Palma de Mallorea: Trabajos del Museo de Mallorca 1.

Serra, $M^{\text {a. }}$ L. 1965. La naveta oriental de Biniac (Alayor, Menorca). Pyrenae 1, 73-84.

Serra, Ma.L., Rosselló-Bordoy, W. \& Orfila León, J.A. 1977. Historia de Menorca. 1. Maó: Universitat de la Illa de Menorca.

Serra, M ${ }^{a}$ L. \& Rosselló-Bordoy, G. 1971. Excavación y restauración de la naveta meridional de Rafal Rubí (Alayor, Menorca). Noticiario Arqueológico Hispánico $16,53-74$.

Stuiver, M. 1969. Yale Natural Radiocarbon Measurements. Radiocarbon 11(2), 545-658.

Stuiver, M. \& Reimer, P.J. 1993. Extended ${ }^{14} \mathrm{C}$ data base and revised Calib $3.0{ }^{14} \mathrm{C}$ age calibration program. Radiocarbon 35, 215-30.

Strydonck, M. van, Forest, L., Landrie, M., Hendrix, V., Borg, K. van der \& Jong, A.F.M. de. 1995. Royal Institute for Cultural Heritage. Radiocarbon Dates 15. Brussels: Institute Royal du Patrimoine Artistique.

Tarradell, M. 1964. La Necrópolis de Son Real y la Illa dels Porros. Excavaciones Madrid: Arqueológicas en España 24.

Tarradell, M. 1970. Dos nuevas fechas de C. ${ }^{14}$ para Villena y Mallorca. Papeles del Laboratorio de Arqueología de Valencia 10, 19-26.

Veny, C. 1947. La necrópolis de la cueva Cometa dels Morts, cerca de Lluch, en Mallorca. Archivo Español de Arqueologia 21 66, 46-59.

Veny, C. 1968. Las Cuevas Sepulcrales del Bronce Antiguo de Mallorca. Madrid: Bibliotheca Praehistorica Hispana 9.

Veny, C. 1970. Un avance sobre la necrópolis de Cales Coves (Menorca, Baleares). Trabajos de Prehistoria 27, 97-167.

Veny, C. 1974. Anotaciones sobre la cronología de las navetas de Menorca. Trabajos de Prehistoria 31, 101-42.

Veny, C. 1976a. Dos cuevas del bronce antiguo de Menorca y su incidencia en las navetas. Trabajos de Prehistoria 33, 227-49.

Veny, C. 1976b. Excavaciones en la naveta de Son Morell (Menorca). Noticiario Arqueológico Hispánico 5, 223-8.

Veny, C. 1977. Apuntes complementarios sobre la cueva de la Edad del Hierro de Son Maimó, Petra (Mallorca). Trabajos de Prehistoria 34, 111-54.

Veny, C. 1981. El complejo funerario de una galeria subterránea de la Cometa dels Morts. Lluc, Escorca (Mallorca). 'Trabajos de Prehistoria 38, 257-80. 
Veny, C. 1982. La naveta de La Cova. Trabajos de Prehistoria 39, 73-136.

Veny, C. 1983. Cueva II de la Cometa dels Morts (Escorca, Mallorca). Noticiario Arqueológico Hispánico 15, 342-58.

Waldren, W.H. 1982. Balearic Prehistoric Ecology and Culture. The Excavation and Study of Certain Caves, Rockshelters and Settlements. Oxford: British Archaeological Report S149.

Waldren, W.H. 1984. Chalcolithic settlement and Beaker connections in the Balearic Islands. In W.H. Waldren et al. (eds) 1984, 911-65.

Waldren, W.H. 1986. The Balearic Pentapartite Division of Prehistory. Radiocarbon and Other Age Determinations Inventories. Oxford: British Archaeological Report S282.

Waldren, W.H. 1990. Prehistoric Architectural Elements. Ferrandell-Oleza Chalcolithic Old Settlement (Valldemossa, Mallorca, Baleares, Spain). Deià: DAMARC 20.

Waldren, W.H. 1992. Radiocarbon and Other Isotopic Age Determinations From the Balearic Islands. A Comprehensive Inventory. Deià: DAMARC 26.

Waldren, W.H. (nd). Radiocarbon Determination in the Balearic Islands. Oxford: Baden-Powell Quaternary Research Centre.

Waldren W.H., Chapman R.W., Lewthwaite, J.G. \& Kennard, R.-C. (eds). 1984. The Deià Conference of
Prehistory. Early Settlement in the Western Mediterranean Islands and Peripheral Areas. Oxford: British Archaeological Report \$229.

Waldren, W.H., Ensenyat Alcover, J. \& Cubi, C. 1989. Son Mas. Balearic Prehistoric Sanctuary (circa 2000 BC to 1750 BC) Valldemossa, Mallorca, Baleares, Spain. Preliminary Report. Deià: DAMARC.

Waldren, W.H., Ensenyat Alcover, J. \& Cubi, C. 1990. Prehistoric Architectural Elements: Ferrandell-Oleza Chalcolithic Old Settlement, Valldemossa, Mallorca, Baleares, Spain. Deià: DAMARC 20.

Waldren, W.H., Ensenyat Alcover, J. \& Morell, C. 1988. Son Mas. Balearic Prebistoric Sanctuary (circa 2000 BC to 1750 BC) Valldemossa, Mallorca, Baleares, Spain. Preliminary Report. Deià: DAMARC.

Waldren, W.H. \& Plantalamor, Ll. 1975. Cainpaña de excavaciones en el abrigo de Son Matge (Valldemossa, Mallorca. 1973). Noticiario Arqueológico Hispánico 5, 243-6.

Waldren, W.H. \& Rosselló-Bordoy, G. 1975. Excavaciones en la Cueva de Muleta (Sóller, Mallorca). Noticiario Arqueológico Hispánico 3, 73-123.

Waldren, W.H. \& Strydonck, M. van. 1992. A Radiocarbon Analysis Survey Dating the Activity Sequences of the Sanctuary. Prehistoric Sanctuary of Son Mas (Valldemossa, Mallorca, Baleares, Spain). Deià: DAMARC 24. 
3. P.V. Castro Martínez et al. RADIOCARBON DATING AND BALEARIC PREHISTORY

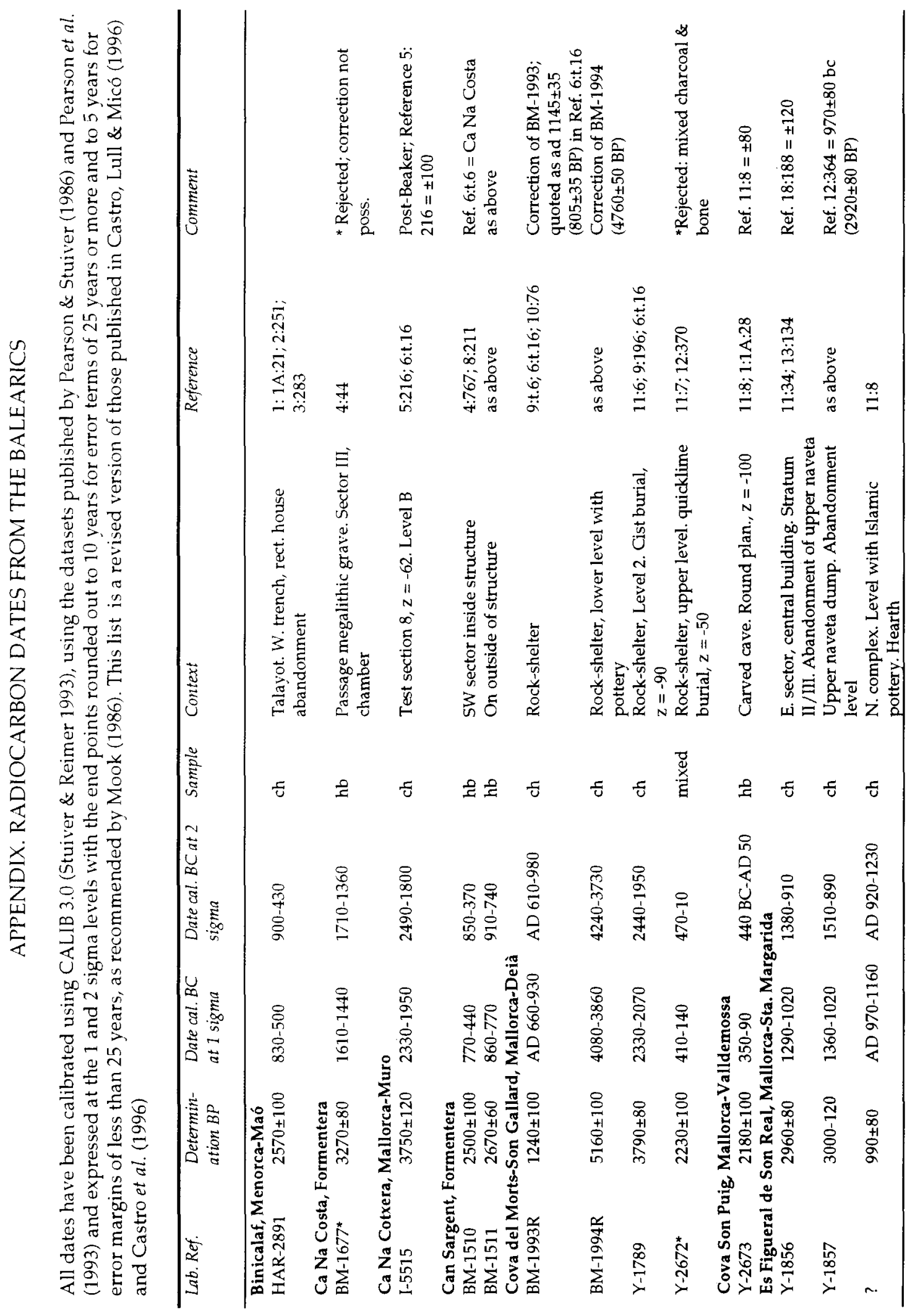


THE PREHISTORIC SOCIETY

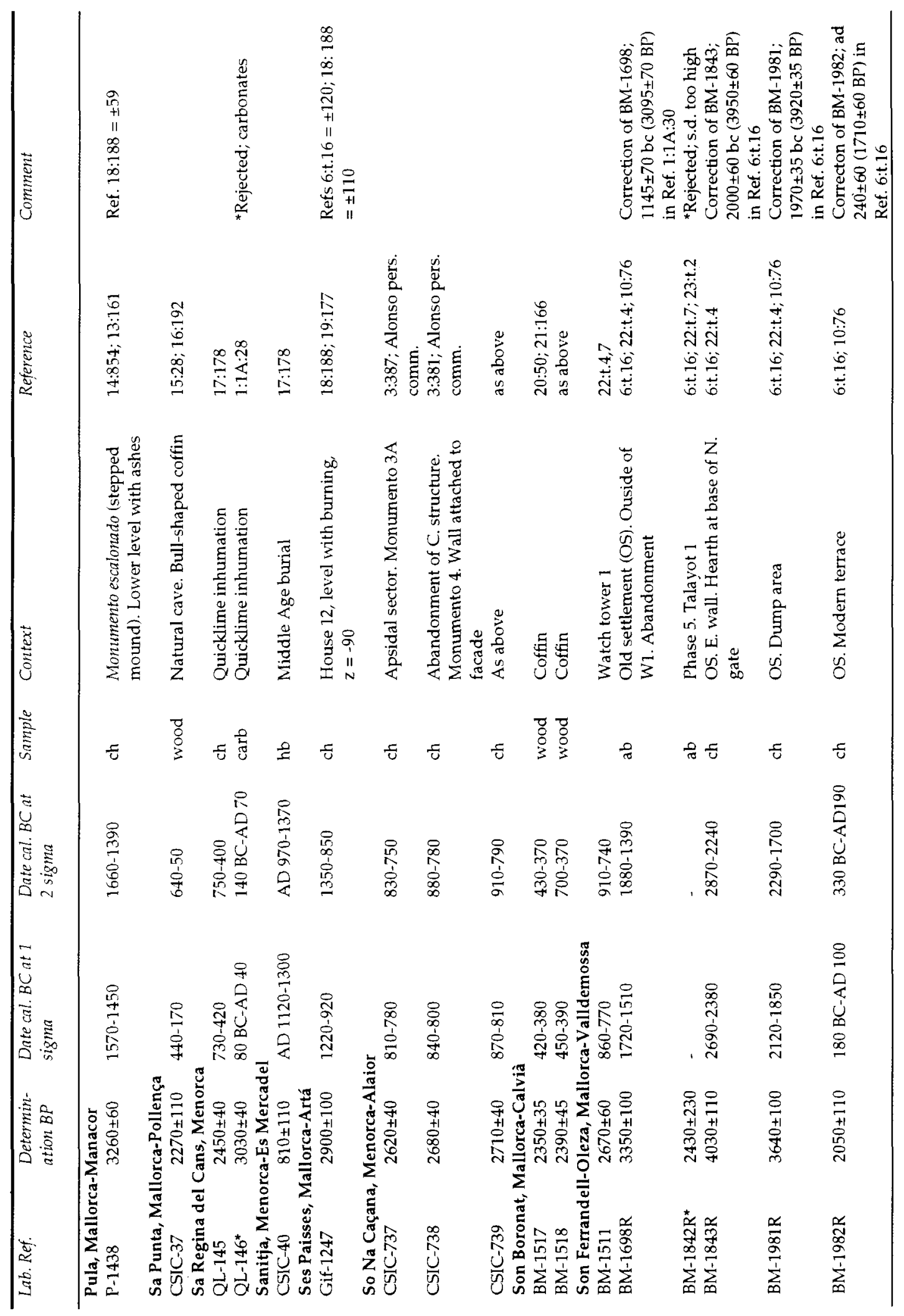




\section{P.V. Castro Martínez et al. RADIOCARBON DATING AND BALEARIC PREHISTORY}

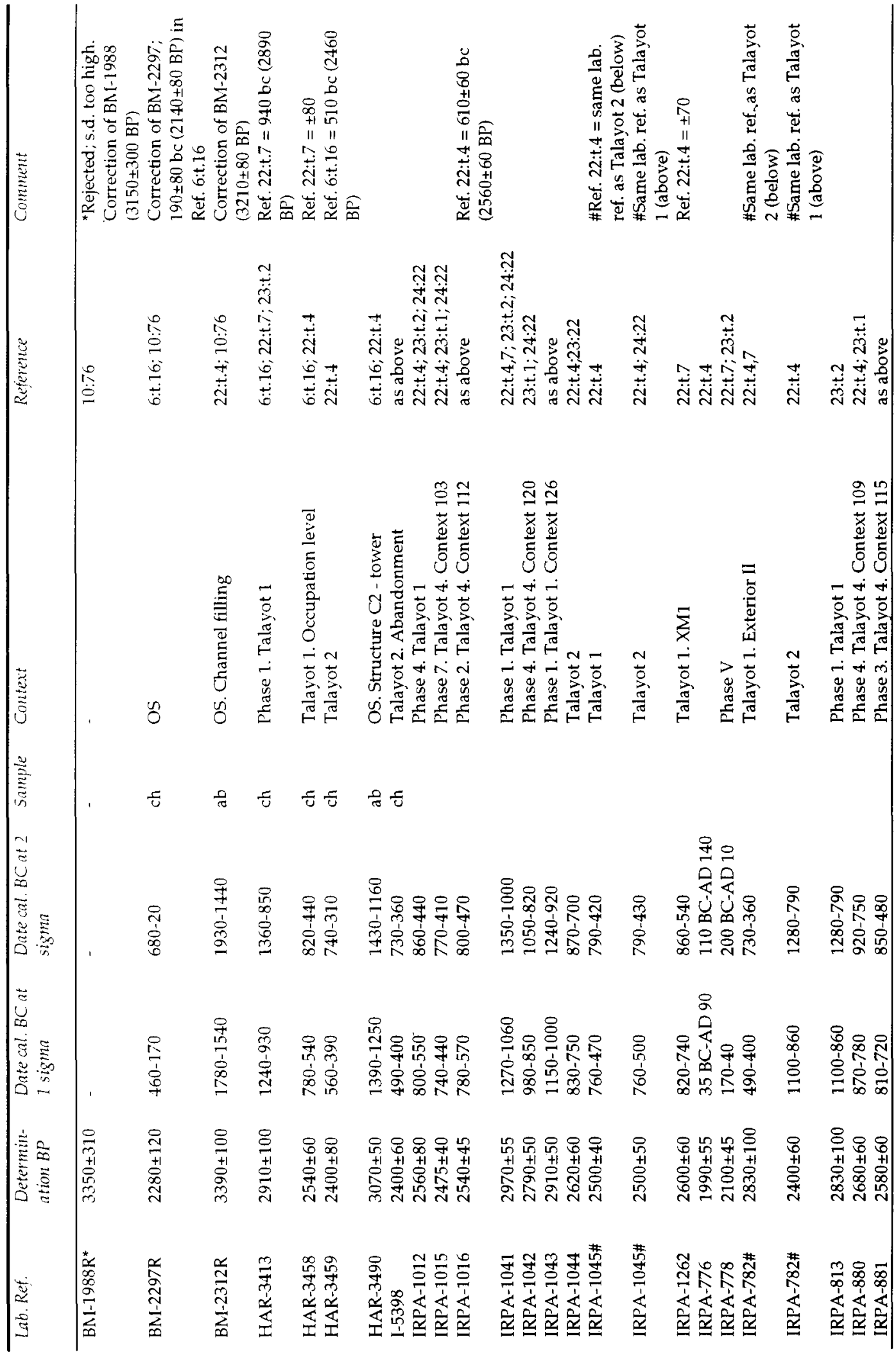


THE PREHISTORIC SOCIETY

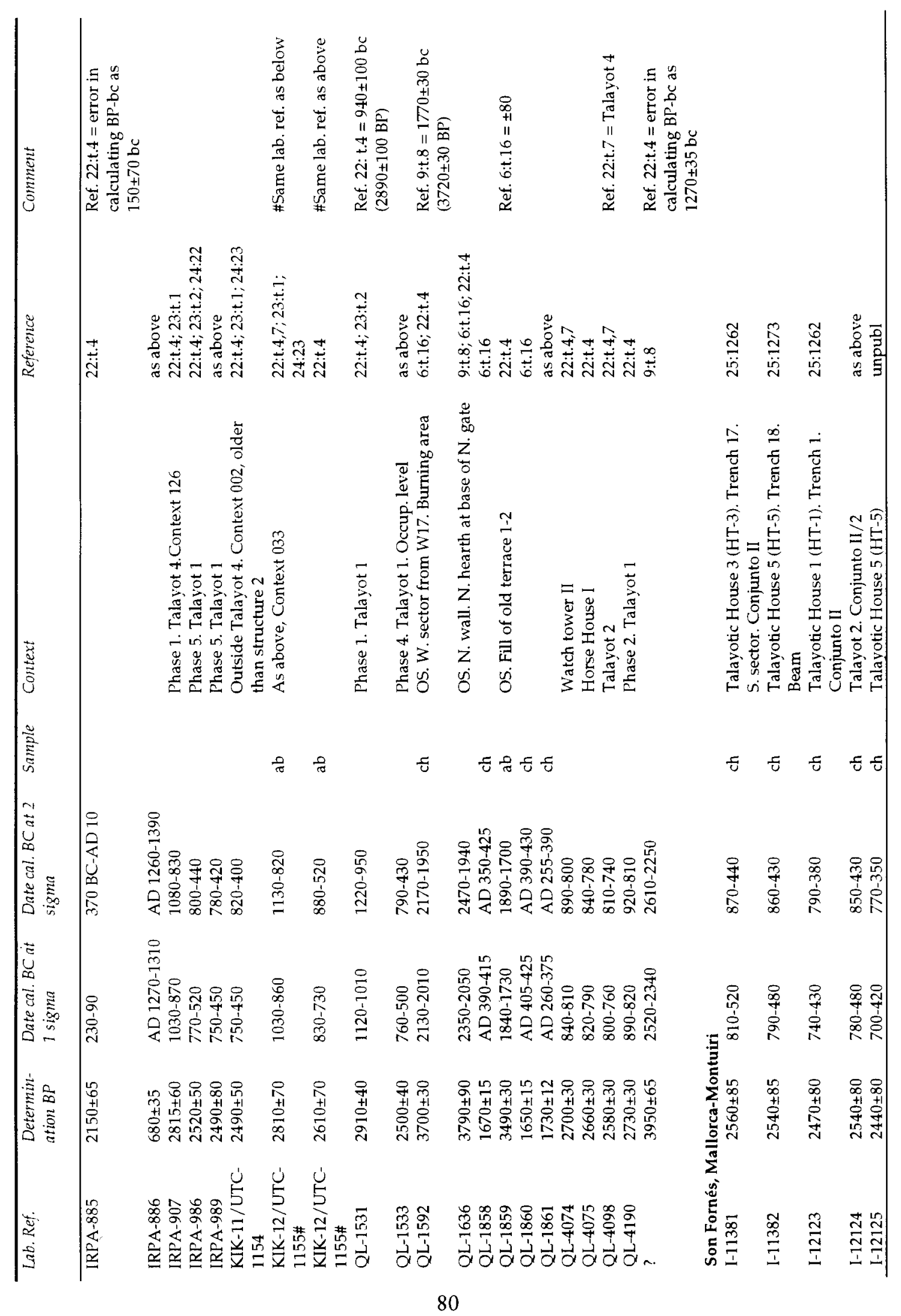


3. P. V. Castro Martinez et al. RADIOCARBON DATING AND BALEARIC PREHISTORY

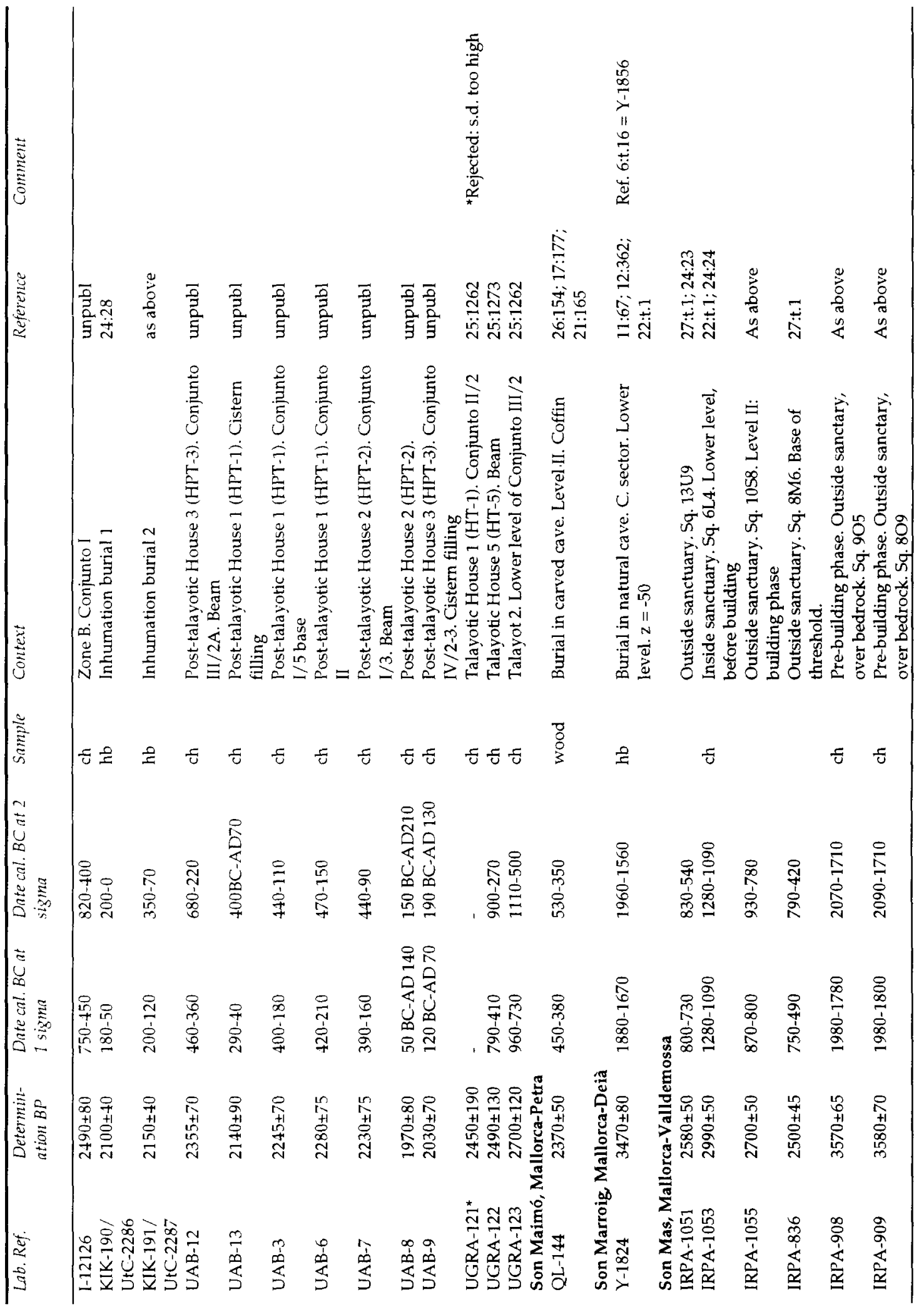


THE PREHISTORIC SOCIETY

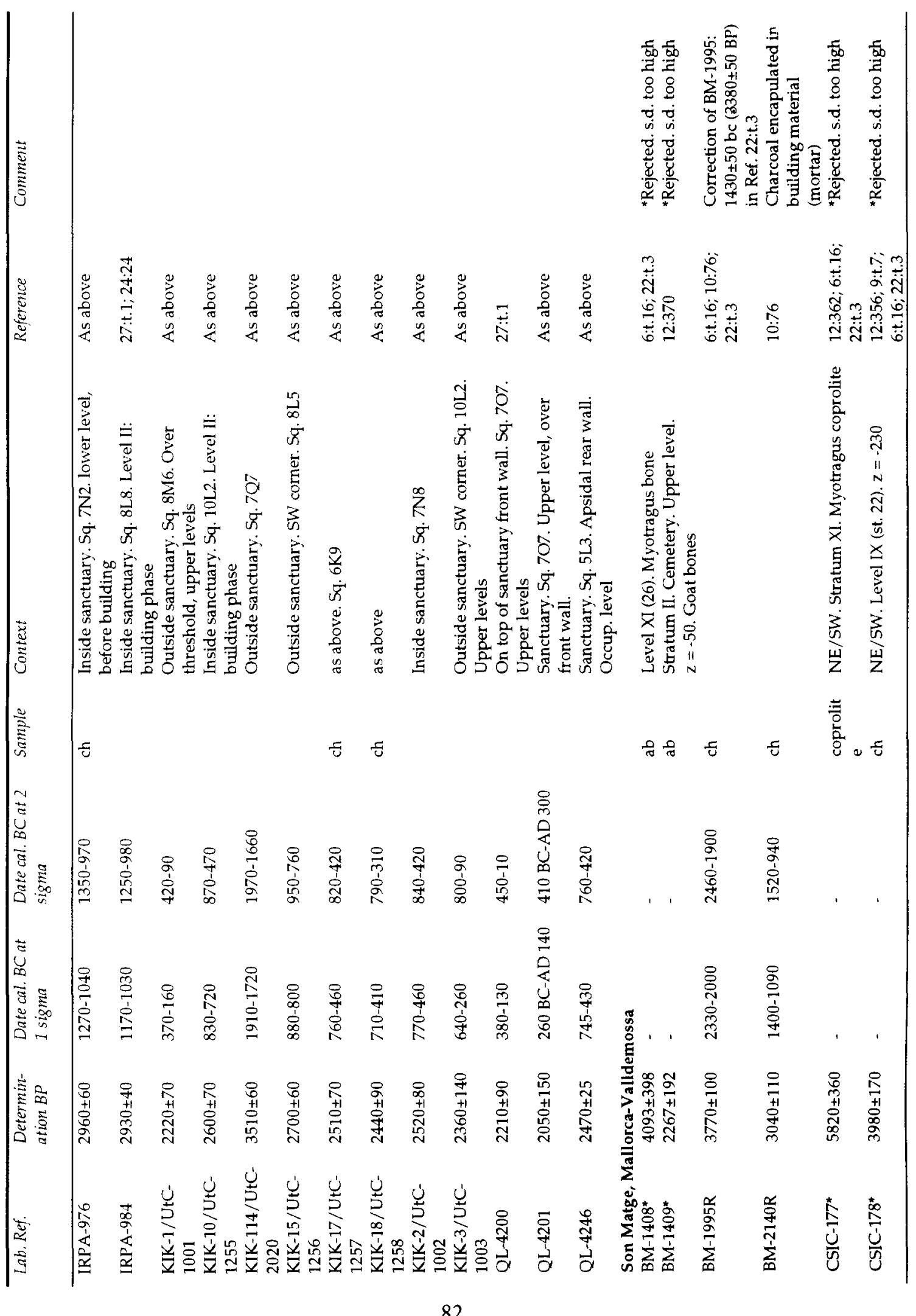




\section{P. V. Castro Martínez et al. RADIOCARBON DATING AND BALEARIC PREHISTORY}

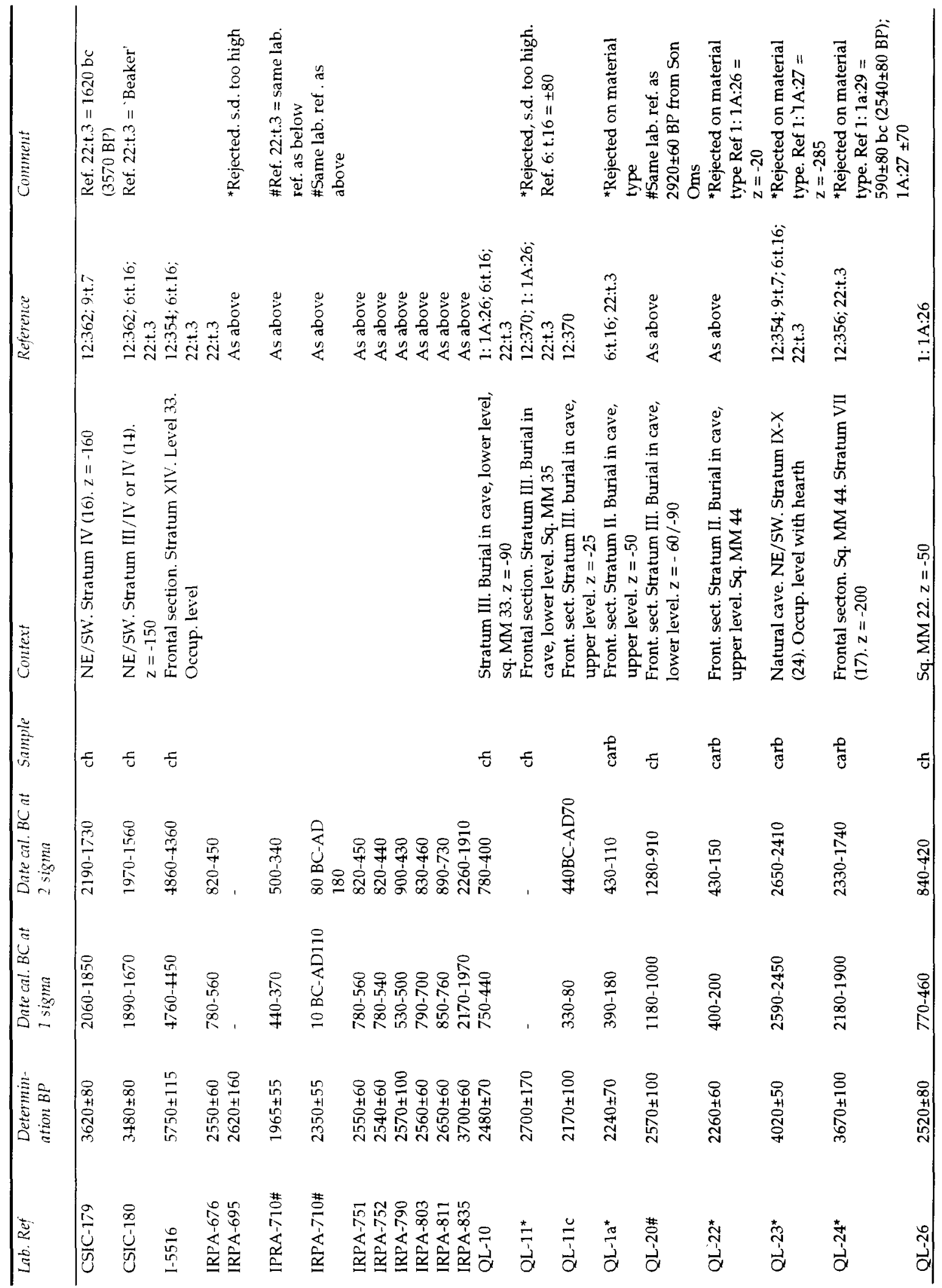


THE PREHISTORIC SOCIETY

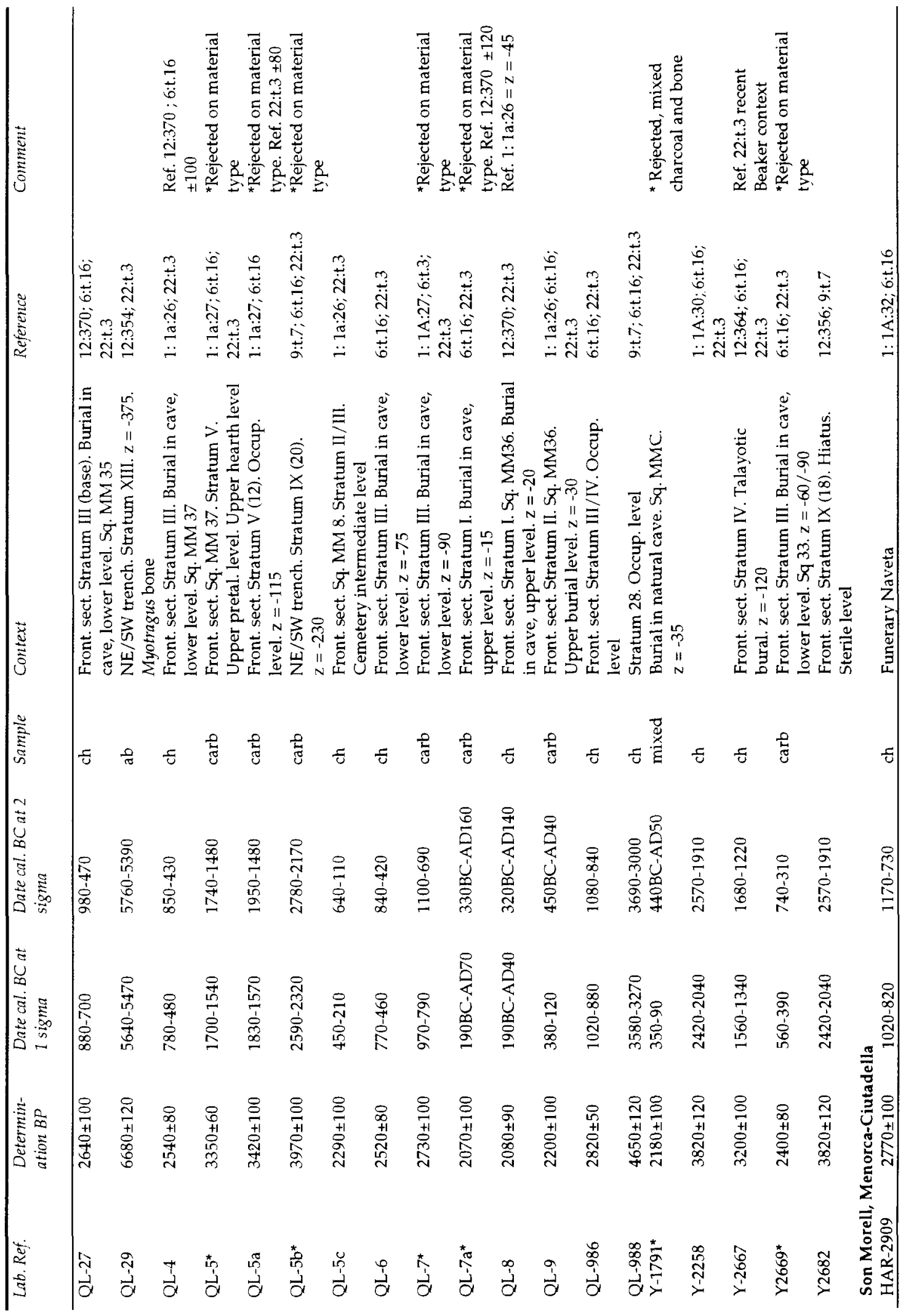




\section{P.V. Castro Martínez et al. RADIOCARBON DATING AND BALEARIC PREHISTORY}

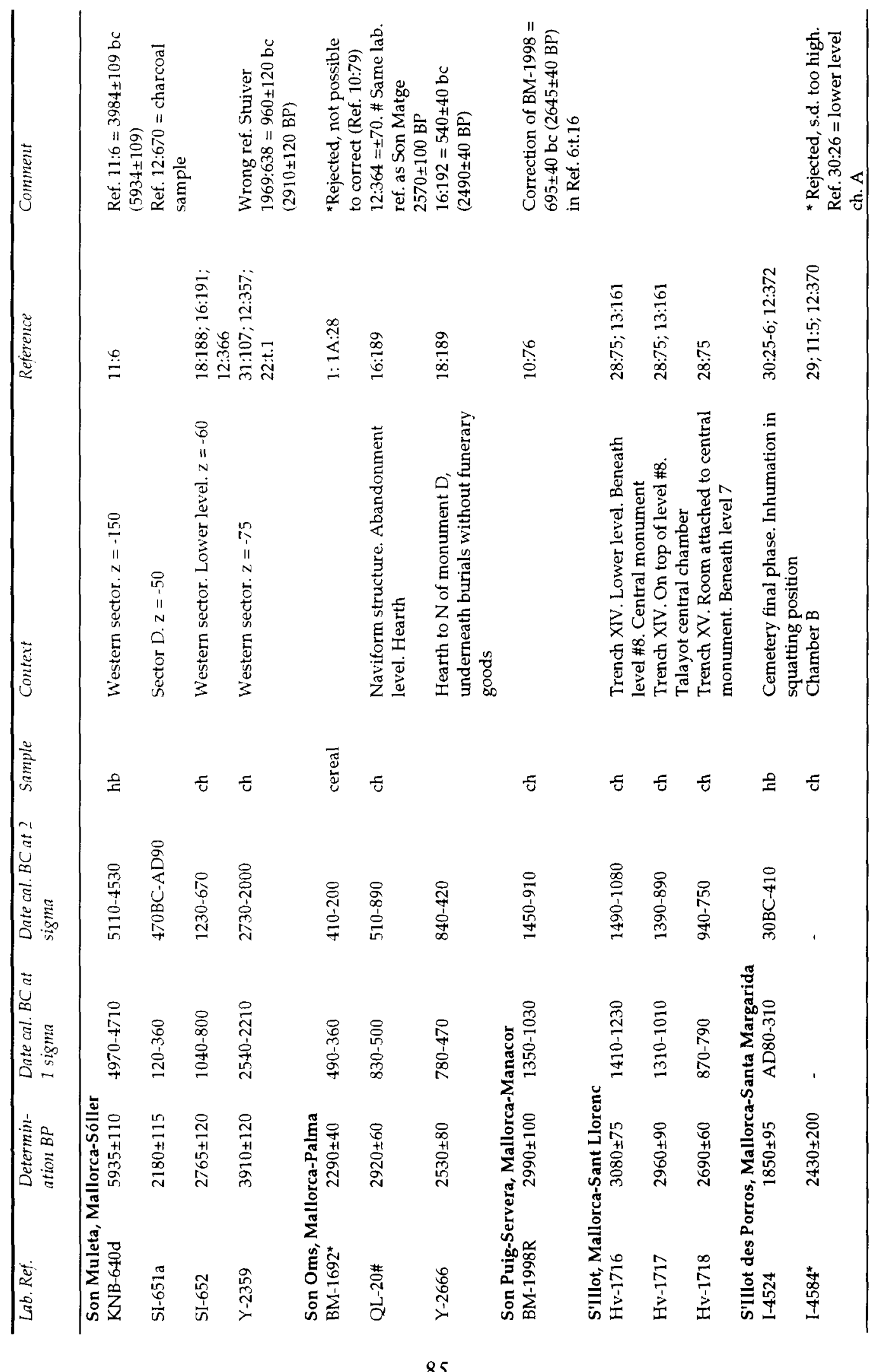


THE PREHISTORIC SOCIETY

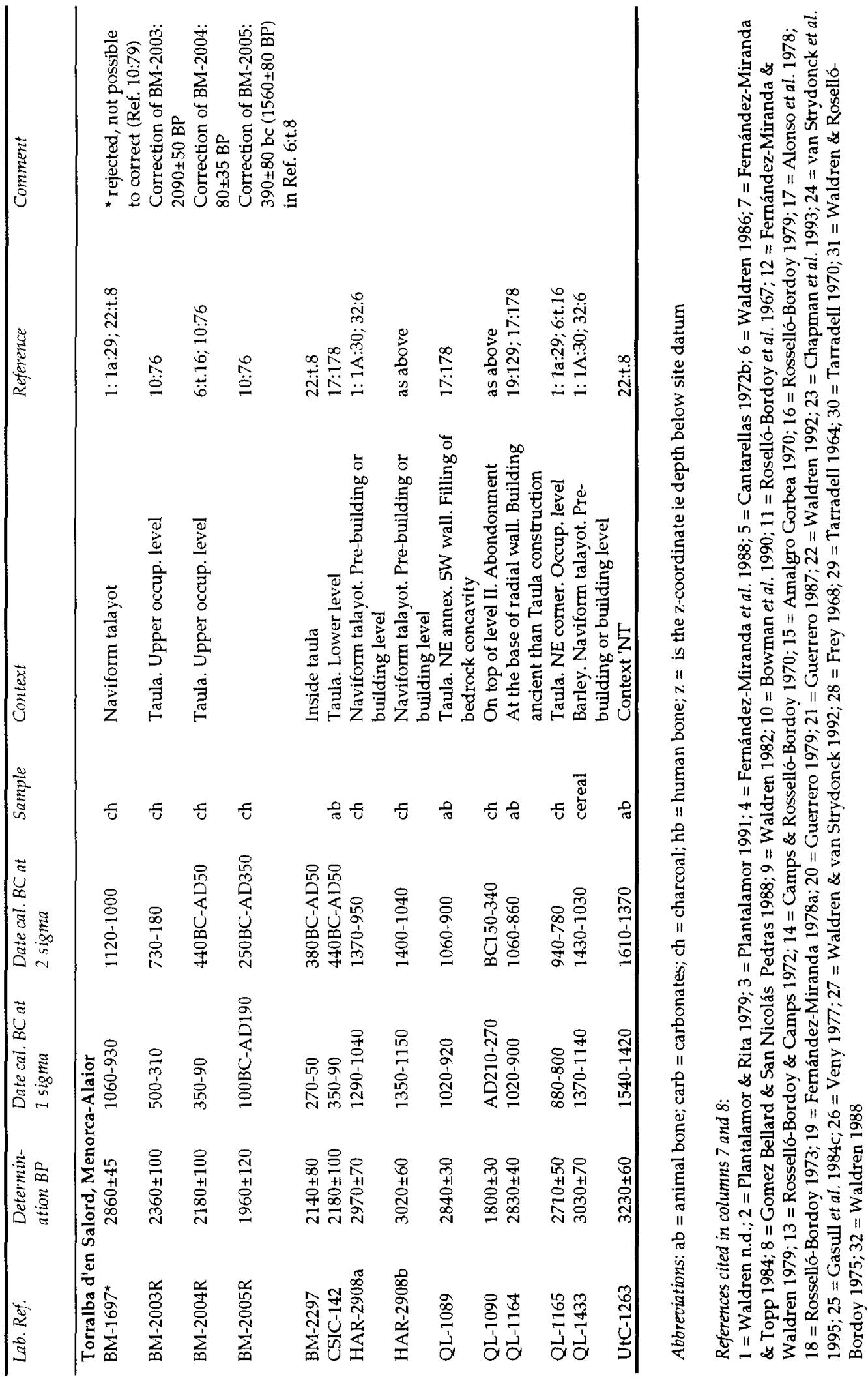

